\title{
Clean Electricity, Dirty Electricity: The Effect on Local House Prices
}

\author{
Piet Eichholtz ${ }^{1} \cdot$ Nils Kok $^{1} \cdot$ Mike Langen $^{2}$ (D) . Daan van Vulpen ${ }^{3}$
}

Accepted: 4 November 2021 / Published online: 10 December 2021

(C) The Author(s) 2021

\begin{abstract}
Renewable energy production is one of the most important policy instruments to fight climate change. However, despite global benefits, renewable energy production entails some local challenges, such as requiring more space per unit production capacity. In this paper, we study the external effects of large-scale conventional and renewable electric power generation facilities on local house prices. We combine information of all coal, gas, and biomass plants, as well as all wind turbines in the Netherlands, with 1.5 million housing transactions over a period of 30 years. Using a difference-in-difference as well as a repeated sales model, we study the effects of facility openings and closings. Our results show negative external price effects for gas plants and wind turbines, but positive effects for biomass plants, conditionally upon ex-ante lower priced locations. The external effects of power generating facilities on local housing markets are important to consider, especially with the current focus of public policies on the expansion of renewable energy generation. Our paper is one of the first to present a large-scale study, using detailed information, and comparing several different energy sources in one framework.
\end{abstract}

Keywords Renewable energy $\cdot$ Wind power - Coal plants · Housing markets · Residential real estate

JEL Classification O13 · Q42 · Q43 · Q51 · R31 · R52

Mike Langen

m.langen@ reading.ac.uk

1 Maastricht University, Maastricht, The Netherlands

2 University of Reading, Reading, UK

3 Amsterdam, The Netherlands 


\section{Introduction}

Electricity consumption in the European Union is expected to increase by between 0.5 and 1 percent per year until 2030 (European Commission, 2013). To reliably handle this energy demand, a large fraction of electricity is currently generated by coal and gas-fired power plants. Such an increase will lead to significant environmental externalities. To combat this, there is a strong desire among policy makers to become less dependent on fossil fuels, and to decrease carbon emissions from power generation, mostly through the increasing use of renewable energy sources.

In Europe, the European Commission passed its Europe 2020 strategy, which binds all EU member states to reduce greenhouse gas emissions by 20 percent and to increase the share of renewable electricity production to 20 percent by the year 2020. Over recent years, the share of renewable electricity production in the EU-28 increased from 12.6 percent in 2003 to 22.4 percent in 2014 (European Commission 2015, 2016; Eurostat 2015a, b). But, this average comes with significant variation across individual member states, putting pressure on some countries to more rapidly increase their share of renewables.

The question of whether renewable (or "green") electricity generation is a superior solution to conventional generation is a multi-dimensional question that involves a comprehensive cost-benefit analysis regarding electricity prices and production costs, available capacity, and environmental aspects. In order to compare the total costs of different types of electricity production, their external costs to the environment should also be incorporated in the calculations, in addition to direct costs (Ayres \& Kneese, 1969; Roth \& Ambs, 2004). Besides global environmental externalities, local effects of power generation on public health, as well as the effects of noise and sight for the nearby population are important to consider. Externalities on the local environment often lead to popular opposition when governments plan to expand on renewable energy generation (Breukers \& Wolsink 2007; Wolsink 2000, 2007; Wüstenhagen et al. 2007). However, EU member states have initiated a multitude of national policies to increase the share of renewable energy, often ignoring these local externalities.

This paper fills the research lacuna by analyzing the external effect of conventional power plants (coal and gas) and renewable power plants (wind and biomass) on local housing prices, determining the costs of different types of electricity generation for local home owners. We employ a comparable analytical framework within similar housing markets, using an extensive, longitudinal dataset of actual transaction prices. We focus on opening and closing effects of different energy generation types due to the importance of ex-ante location controls.

We address a comparability problem, since the current literature is mostly limited on the external effects of a single type of electricity generation or the general effect of power plants, not distinguishing between types. Furthermore, existing studies often analyze just a few power plants at the time, use different and non-comparable analytical tools, or employ asking prices rather than transaction prices to assess effects on local house prices (Blomquist, 1974; Clark et al., 1997; Davis, 2011; Dröes \& Koster, 2016; Gamble \& Downing, 1982; Gibbons, 2015; Heintzelman \& Tuttle, 2012; Lang \& Opaluch, 2013; Sunak \& Madlener, 2016). It is therefore difficult to draw a 
coherent conclusion about the relative effects of different types of electricity generation on local housing markets.

In any study of externalities and house prices, endogeneity is a critical issue in properly identifying effects. In our analysis, an endogeneity problem arises from the fact that placement decisions of power plants and wind turbines depend on factors like available infrastructure and local politics, but also on land values. Since electricity production requires significant space, land prices are a considerable factor in setup costs. Land value is also a determinant of house prices, so it could be argued that land values and house prices in affected areas are likely to already be lower before the placement of a power plant or wind turbine. This leads to an identification problem that is often neglected in the existing literature, when using hedonic models (Sunak \& Madlener, 2016).

This study focuses on the Netherlands, which is lagging behind other European countries, such as Sweden and Denmark, in renewable electricity generation. The share of Dutch renewable electricity production was 6 percent in 2014. Among renewables, biomass/renewable waste (5.3 percent) and wind ( 0.7 percent) are the dominant energy sources (Eurostat, 2015b). A critical goal of Dutch energy policy is to rapidly increase the share of renewable electricity sources. As wind is abundant along the Dutch coast, the plan is to have 6,000 megawatt (MW) of onshore wind capacity installed by 2020 , increasing the number of wind turbines and partly replacing older, less efficient wind turbines (Londo \& Boot, 2013). Since the Netherlands is one of the most densely populated countries in Europe, electricity generation and urban areas are likely to further converge, raising the question of how external effects of different electricity generation types affect the housing market?

To address this question, we employ an extensive dataset of 2.3 million Dutch housing transactions between 1985 and 2015. In addition, we have data on all wind turbines, biomass plants and conventional power plants in the Netherlands. We focus on coal, gas, biomass and wind electricity generation facilities, since these are most significant for the Dutch electricity market. ${ }^{1}$ We match these information sources in order to measure the effects of proximity to electricity generation facilities on house prices, calculating distance measures for each individual transaction, using a variety of models to control for individual housing characteristics.

We document different external effects on nearby house prices for different energy types. We find negative external effects for gas plants and wind turbines. In contrast, we find positive price effects for biomass plants, conditionally on placement in exante lower priced areas. We do not find any significant price effects for coal plants. ${ }^{2}$ All external effects are generally negative in urban areas. Most effects are robust over time and do not vary with plant size. As plant size plays no role, the general negative effect might at least partially come from perception.

\footnotetext{
${ }^{1}$ Nuclear power contributes to the Dutch electricity market, but there is only one power plant in the Netherlands (the Borssele nuclear power plant). Due to its singularity, observations within externality distance would be limited and potential results hardly generalizable. We therefore exclude the nuclear plant from our analysis.

${ }^{2}$ Due to limited openings, we are only able to examine coal plant closings with sufficient observations.
} 
The remainder of this paper starts with a short discussion of the literature regarding the external effects of electricity generation on local housing markets. Section three presents a theoretical framework and the underlying methodology, which is followed by section four, providing the data and descriptive statistics. Sections five describe the results and section six of the paper offers a short conclusion.

\section{Literature Review}

\section{External Effects of Electricity Generation}

Defining and pricing externalities of electricity generation facilities is a challenging task. Roth and Ambs (2004) provide a meta-study to quantify the externality costs of 14 different electricity generation types, focusing on air pollutants. They find a wide range of damage cost estimations of individual air pollutants, such as for carbon dioxide $\left(\mathrm{CO}_{2}\right)$, ranging from $\$ 9.90$ to $\$ 41.60$ per ton, with coal power plants having the highest external costs, followed by gas and combined cycle power plants. In contrast, biomass and wind appear to have only limited external costs. These results are in line with a study conducted by the European Commission (2003). However, despite a common agreement over the rank of air pollution emission among electricity generation types, cost estimates of different emissions vary widely, showing the difficulty of pricing the externalities of electricity generation.

Despite the lack of air pollution stemming from wind turbines, there are significant noise and visual effects. Reported health effects such as sleep disturbance, headache, anger fatigue and loss of motivation are acknowledged as factors that can be caused by the noise from wind turbines (Farboud et al., 2013). ${ }^{3}$ Visual effects seem to have an even stronger impact than noise (Bakker et al., 2012). Even though there is no scientific evidence about causal effects, people located near wind turbines have reported health effects, claiming those effects were due to photo-induced seizures (photosensitive epilepsy) and wind turbine blade flicker (Harding et al., 2008). In addition, households located nearby report a decrease in life-satisfaction after the installation of wind turbines (Krekel \& Zerrahn, 2017).

The increased number of self-reported health effects by people living near wind turbines merely seems to be caused by the annoyance over the presence of wind turbines itself, rather than originating from one aspect in particular, highlighting the difficulty to identify individual externalities (Pedersen \& Waye, 2007). ${ }^{4}$ People generally support wind energy, but oppose it if facilities are installed close to their homes (Breukers \& Wolsink 2007; Wolsink 2000, 2007; Wüstenhagen et al. 2007). Wolsink (2007) states that local residents are willing to accept wind turbines in their vicinity

\footnotetext{
${ }^{3}$ Other health effects mentioned in the study are: visceral, vibratory and/or vestibular dysfunction, dizziness, vertigo, unsteadiness, tinnitus, ear pressure or pain, external auditory canal sensation, memory and concentration deficits, and irritability.

${ }^{4}$ In the Netherlands, the noise and shadow effects of wind parks on nearby neighborhoods are assessed before opening, protecting nearby residents from increased exposure https://bit.ly/2X0yQfC. It is therefore difficult to pinpoint specific negative effects of wind turbines.
} 
as long as they perceive the general distribution of wind turbines as "fair". However, in the Netherlands local residents do not have the perception that they can influence the distribution of new wind turbine sites (Wüstenhagen et al., 2007). ${ }^{5}$ Similar results are found in the United Kingdom (Bell et al., 2005), the United States (Pasqualetti, 2011b), and Mexico (Pasqualetti, 2011a).

\section{Power Plants and External Effects on Housing}

Since residential real estate is fixed in location, prices are highly sensitive to factors disrupting location quality (Hilber, 2005), making real estate a good identifier of local utility or disutility from externalities. As people choose locations according to their preferences and aversions (Tiebout, 1956a), external factors, that arise from power plants and wind turbines, are incorporated in house prices (Rosen, 1974), allowing to assign monetary values to the external effects. ${ }^{6}$ However, since it is practically impossible determine and measure all external effects of different electricity generation facilities, we use distance (proximity) to properties as a measure in the Rosen (1974) framework. Using distance should theoretically reflect the net-external effects (Nelson, 2008).

Research focusing on local housing market effects of power plants dates back more than 40 years. However, most studies focus on the effects of individual power plants in small regional markets (Blomquist, 1974; Clark et al., 1997; Gamble \& Downing, 1982; Sunak \& Madlener, 2016). Large-scale studies tend to investigate just one type of electricity production, using different measures of property prices, such as transaction-based (Dröes \& Koster, 2016) or survey-based (Davis, 2011). Additionally, studies use different control variables, leading to varying empirical models. Due to the heterogeneous characteristics of housing markets, changes in electricity generation technology over time, and the focus on a single type of electricity generation, it is hard to draw a coherent conclusion about the relative effects of different electricity generation types on local house prices.

In most studies, the observed external effects for conventional power plants and wind turbines are either negative or insignificant. Blomquist (1974) finds a price decrease of 0.9 percent per 500 feet, within a 2-mile distance of a coal power plant. Davis (2011) finds a discount of 3 to 7 percent within 2 miles of plants, increasing with proximity and capacity. For wind turbines, negative external effects range between 5 percent within 0.5 miles (Lang \& Opaluch, 2013), 2 to 16 percent within 3 miles (Heintzelman \& Tuttle, 2012), 1.2 to 2.6 percent within 2 kilometers (Dröes \& Koster, 2016) and 5 to 6 percent within 2 kilometers (Gibbons, 2015). Other studies find no evidence of significant effects (Carter, 2011; Hoen, 2014; Sims et al., 2008). Since the methodology, number of observations, research area and control variables differ widely between studies, it is not possible to directly compare these findings and

\footnotetext{
${ }^{5}$ This perception is confirmed by the fact that the Dutch Ministry of Infrastructure and the Environment centrally determined eleven areas for the construction of new wind parks in 2014. The official selection criteria were population density and wind speed (Feld et al., 2014).

${ }^{6}$ The main assumption is that people are free in their location choice.
} 
to draw firm conclusions regarding the relative externality costs of different forms of electricity generation.

Overall, there is no study that simultaneously includes different types of electricity generation technology, uses a large number of observations, measures transactionbased house prices, and accounts for sufficient control variables to quantify external effects in a comparable manner. Furthermore, in any study addressing the effect of locally desirable or undesirable externalities on house prices, the main challenge is identification. In the case of power plants, both renewable and conventional, the locational choice is often driven by factors such as land values and (local) politics, rather than being fully random or based on exogenous factors such as proximity to waterways or exposure to a stiff breeze. Only a few, recent studies address this issue (Davis, 2011; Dröes \& Koster, 2016).

\section{Method}

\section{Theory \& Sample Construction}

We study the effects of different electricity generation methods on house prices within one market: The Netherlands. Our focus is on coal, gas, biomass, and wind energy, due to their significance for the local electricity market. Since the findings of previous studies differ widely, we are interested in the variation of external effects between different electricity generation facility types and the variation of findings due to different model specifications. We therefore test two specifications: a difference-in-difference (DID) approach using average area price changes (e.g. see Muehlenbachs et al. 2015; Pope \& Pope 2015), and a DID repeated sales model.

For both approaches, we use a similar measure of externality exposure. Since we cannot determine and measure all potential externalities of the different electricity generation facilities, we assume that externalities spread over distance (Nelson, 2008). As we focus on local external effects of electricity generation facilities and neglect global effects, such as $\mathrm{CO}_{2}$ emissions, we focus on areas directly surrounding electricity generation facilities. However, it might be that different externalities spread differently over distance. In contrast to physical externalities such as noise and sight disturbance, economic externalities, such as employment effects, could reach further, leading to potentially unbalanced external effects over distance.

Assuming external effects spread over distance, we determine exposure to externalities by the linear distance to the closest electricity generation facility of every energy type, using longitude and latitude information. ${ }^{7}$ Based on a cut-off distance, we consider observations as either affected by externalities $(d=1)$ or not affected $(d=0)$. Based on empirical findings on conventional plants (Davis, 2011) and wind turbines (Dröes \& Koster, 2016), we use a cut-off distance of $2.5 \mathrm{~km}$ for all energy types. However, we further examine different cut-off distances and interval measures.

\footnotetext{
${ }^{7}$ Distances are calculated using the haversine formula, a common way to calculate the great-circle distance of two points on a sphere using longitude and latitude information.
} 


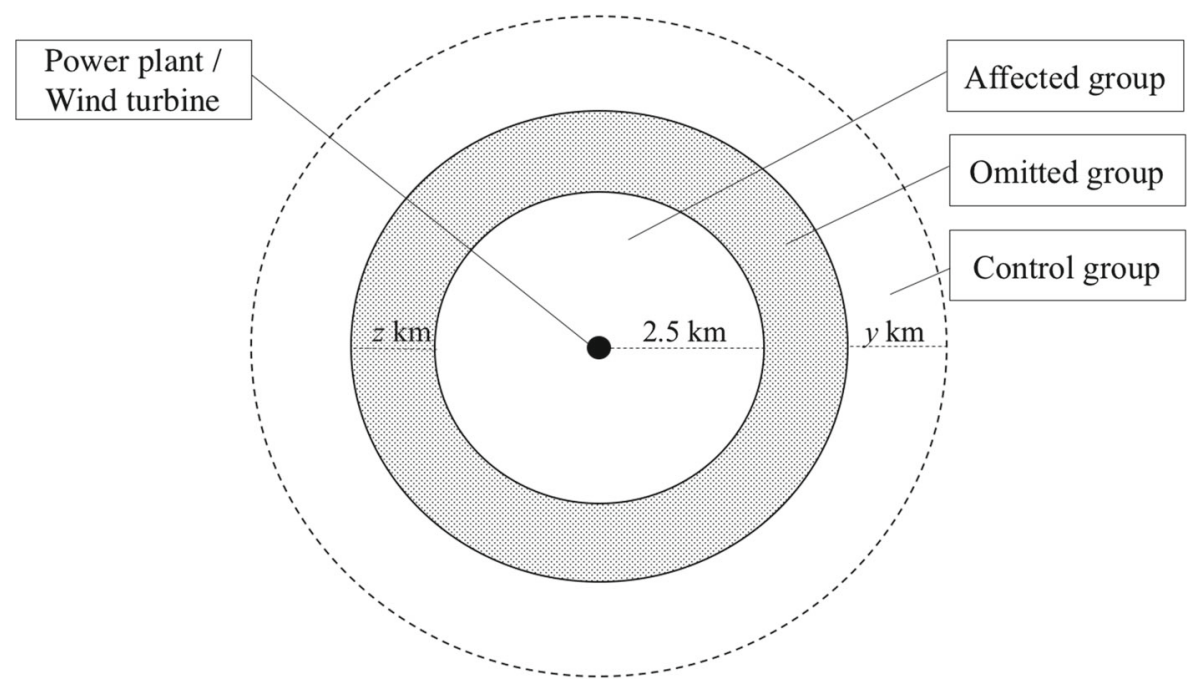

Fig. 1 Sample Construction Method. Notes: We cluster observations into affected, omitted and control groups depending on their location relative to a power plant or wind turbine. Observations located in the inner circle around a wind turbine or power plant are considered "affected". We use different radii, ranging from $2.5 \mathrm{~km}$ to $4 \mathrm{~km}$. For the omitted group, we use a radius extension of $z=1.5 \mathrm{~km}$. We consider all other observations as the control group, limiting the maximum distance to $20 \mathrm{~km}(y=16 \mathrm{~km})$

To avoid interference among affected and control observations, we omit observations in a ring-shaped area beyond the cut-off distance as illustrated in Fig. 1. Using the externality cut-off distance of $2.5 \mathrm{~km}$, we consider observations within $2.5 \mathrm{~km}$ distance as affected $(d=1)$, comparing them with control observations beyond $2.5+z$ $\mathrm{km}$, where $z$ is the width of the omitted area. We begin with $z=1 \mathrm{~km}$, but test different lengths for robustness. Due to the heterogeneity of local residential markets, observations at externality distances do not necessarily share the same locational characteristics with observations far away. We therefore control for location fixedeffects and limit our control group to a maximum distance of $10 \mathrm{~km}(y=6.5 \mathrm{~km})$, omitting observations beyond $10 \mathrm{~km}$ distance from the analysis. ${ }^{8}$

We account for confounding factors from other electricity generation facilities. Observations within a $2.5 \mathrm{~km}$ distance of a nuclear power plant are omitted, since there is only one active plant in the Netherlands and we argue that the external effects from nuclear power plants differ from those of conventional plants (Gawande \& Jenkins-Smith, 2001). Furthermore, we exclude observations within a $2.5 \mathrm{~km}$ distance from the German and Belgium border, since we cannot fully account for power plants across the border. ${ }^{9}$

\footnotetext{
${ }^{8}$ We also test other maximum distances between 10 and $20 \mathrm{~km}$ for the control group, not markedly affecting the results.

${ }^{9}$ There are several wind turbines along the German side of the border and some conventional and nuclear power plants in Belgium, not far from the Dutch border.
} 


\section{Difference-in-difference Approach}

Since the placement of power plants and wind turbines is not random, a static model might be biased by an economic endogeneity problem of the price-effect relationship. Besides infrastructure factors, such as grid infrastructure or the closeness to gas pipelines and harbors, and political factors, such as local voter opposition, land value may also determine placement decisions. Low land values make it cheaper to build a power plant or to erect a wind turbine. Since land values strongly correlate with house prices, too, observed house price discounts nearby power plants or wind turbines might be the result of low ex-ante land prices instead (Kok et al., 2014).

Beside limiting the reach of our control group, we address this potential problem by using a difference-in-difference (DID) model, investigating the effects of facility openings and closings. Although our dataset is large, it contains just a limited number of repeated sales pairs. Due to more placements of power plants and wind turbines in remote locations and imbalances in the number of facility openings and closings (e.g. few coal and biomass plant openings and wind turbine closings), we are not able to perform a DID analysis based on repeated sales for all facility types. Instead, we use a difference-in-difference model for geographic areas similar to Muehlenbachs et al. (2015), comparing the change in house prices of areas that experience facility openings / closings, with areas nearby (control areas), as illustrated in Fig. 2.

Equation 1 shows the employed model, testing the effect of facility openings on average property prices, where $F A C_{k i}$ measures if observation $i$ is in proximity to an electricity generating facility of type $k$, either before or after opening, post $t_{k i t}$ $(d=1)$ measures transactions after opening of the closest facility of type $k$, and Treat $_{k i t}=F A C_{k i t} *$ post $_{k i t}$ equals 1 for transactions in close proximity to a facility,

(t)

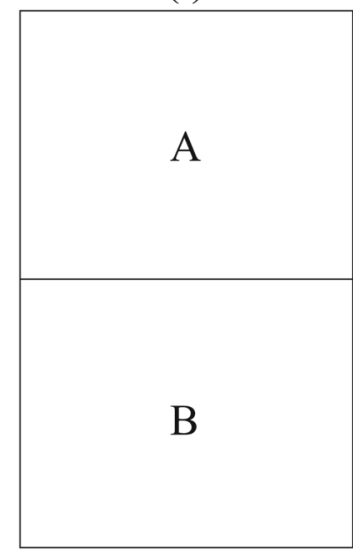

$(\mathrm{t}+\mathrm{x})$

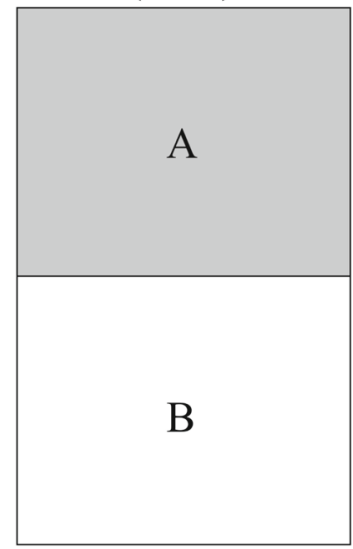

Fig. 2 DID for areas - Setup. Notes: We investigate the average price change of homes in area A comparing it with area $\mathrm{B}$ between time $\mathrm{t}$ and $\mathrm{t}+\mathrm{x}$. Observations in area $\mathrm{A}$ experience the opening / closing of a electricity generation facility of type $\mathrm{k}$ and whereas observations in area B do not. We control for individual housing characteristics to avoid capturing systematic changes in housing characteristics of specifc areas 
after opening. Therefore, the coefficient of interest is $\gamma_{3 k}$, measuring the effect of facility type $k$ openings.

$$
\ln \left(p_{i t}\right)=\alpha+\sum_{k=1}^{K} \gamma_{1 k}\left(F A C_{k i t}\right)+\sum_{k=1}^{K} \gamma_{2 k}\left(\text { post }_{k i t}\right)+\sum_{k=1}^{K} \gamma_{3 k}\left(\text { Treat }_{k i t}\right)+X_{i t} \gamma_{4}+\epsilon_{i t}
$$

We control for unobserved differences in price-determining factors between areas over time and general time-trends, using $X_{i t}$, consisting of structural, environmental and neighborhood characteristics, as well as time fixed-effects (Rosen, 1974). Control variables are listed in Appendix Table 7. We further test for the assumption of common pre-treatment trends (Kuminoff \& Pope, 2014). We account for potential spatial dependence and omitted variables by including neighborhood-fixed effects in $X_{i t}$, hereafter referred to as location FE (Anselin \& Bera, 1998; Kuminoff et al., 2010). ${ }^{10}$ As time-fixed effects we use year dummies, measuring general house price dynamics over time (see e.g. Hoen 2010; Hoen 2014). ${ }^{11}$ Standard errors are clustered by municipality and year.

The analysis is limited to facilities that open during the sample period. We exclude observations around plants that opened before. We only consider observations up to 10 years before and after facility openings, as it can be assumed that long-term price effects settle over time. ${ }^{12}$ To eliminate anticipation effects and effects from construction work, we omit transactions one to two years before openings, as well as the opening year, depending on facility types. ${ }^{13}$ We do not consider observations that experience a replacement, being within externality distance of another facility prior to opening of a new plant. Since the number of affected houses decreases through this filtering process, we also test a 3-km cut-off distance throughout the analysis.

To examine the spatial heterogeneity of external effects, we test the external effects of different electricity generation types at different distance bands. As shown in Eq. 2, we form $J$ distance intervals of $1 \mathrm{~km}$ length up to a distance of $4 \mathrm{~km}$ for every energy type $K$. We use $1 \mathrm{~km}$ length to have sufficient observations in every interval. To reduce complexity, we do not use a holdout distance, meaning we distinguish

\footnotetext{
${ }^{10} \mathrm{We}$ test location fixed effects at 4-digit, 5-digit and 6-digit postcode level, ranging from slightly over 4,000 postcode areas with on average 7,000 households per postcode area to 450,000 postcode areas with 17 households per postcode area. As the results do not change in signs and 6-digit postcode forces us to exclude a large number of observations to avoid individual fixed-effects, we focus on 4-digit postcode level fixed-effects.

${ }^{11}$ Additionally, we adjust house prices for inflation, using the CPI from the Dutch Central Statistics Office (CBS)

${ }^{12}$ We test an extension to 15 years, but do not find a significant difference in results.

${ }^{13}$ The average construction period for conventional plants is two years, whereas the construction period for wind turbines is much shorter, on average. We therefore use one year for wind turbines. Even though projects might be announced earlier, residents in the Netherlands have strong legal power to prolong or abort large projects. We try anticipation periods up to 4 years and adjustment periods up to 3 years, but do not find different results.
} 
between treated observations up to $4 \mathrm{~km}$ and control observations between $4-10 \mathrm{~km}$ distance.

$$
\begin{aligned}
\ln \left(p_{i t}\right)= & \alpha+\sum_{j=1}^{J} \sum_{k=1}^{K} \gamma_{1 j k}\left(F A C_{j k i t}\right)+\sum_{j=1}^{J} \sum_{k=1}^{K} \gamma_{2 j k}\left(\text { post }_{j k i t}\right) \\
& +\sum_{j=1}^{J} \sum_{k=1}^{K} \gamma_{3 j k}\left(\text { Treat }_{j k i t}\right)+X_{i t} \gamma_{4}+\epsilon_{i t}
\end{aligned}
$$

As property prices differ between urban and rural areas (DiPasquale \& Wheaton, 1996), the perception of external effects might differ due to the presence of confounding negative or positive externalities, such as from road noise in cities. We therefore investigate the urban-rural heterogeneity effect, by explicitly controlling for facility openings in urban areas. As shown in Eq. 3, we add an urban location control dummy in the control matrix $X_{i t}$ and add an urban-treatment interaction term represented by $\left(\right.$ Treat $_{k i t} *$ urban $\left._{i t}\right)$, where $\beta_{1 k}$ represents the additional effect of facility type $k$ opening in urban areas. ${ }^{14}$

Due to technical improvements and government regulation, conventional electricity generation facilities typically get cleaner, less noisy, and more efficient over time. ${ }^{15}$ We therefore examine the heterogeneity of opening effects over time, testing subsets of 10-year periods, moving in 5-year steps, as shown in Eq. 1. We use 10-year periods instead of individual years to have sufficient observations for every period, leading to the following, overlapping periods: 1985 - 1995, 1990 - 2000, 1995 - 2005, 2000 - 2010, and 2005 - 2015.

$$
\begin{aligned}
\ln \left(p_{i t}\right)= & \alpha+\sum_{k=1}^{K} \gamma_{1 k}\left(\text { FAC }_{k i t}\right)+\sum_{k=1}^{K} \gamma_{2 k}\left(\text { post }_{k i t}\right)+\sum_{k=1}^{K} \gamma_{3 k}\left(\text { Treat }_{k i t}\right) \\
& +\sum_{k=1}^{K} \beta_{1 k}\left(\text { Treat }_{k i t} * \text { urban }_{i t}\right)+X_{i t} \gamma_{4}+\epsilon_{i t}
\end{aligned}
$$

Another potential source of heterogeneity is power plant size (Davis, 2011) or the number of wind turbines in a wind park (Dröes \& Koster, 2016). Davis (2011) argues to focus on power plants above $100 \mathrm{MW}$, since disamenities are likely to be stronger for these plants. We therefore differentiate for size, using capacity for conventional plants and the number of contiguous wind turbines within a wind park, as capacity differences for individual wind turbines are relatively small compared to power plants. Due to constraints in size variation, we are only able to examine size effects for gas plants and wind turbines. Based on the available variation, we distinguish three size categories for gas plants (<100MW, $100-400 \mathrm{MW},>400 \mathrm{MW})$, and four

\footnotetext{
${ }^{14}$ As mentioned in Appendix Table 7, we also test alternative time fixed-effects, using year-municipality interaction terms. We use municipality as a location as urban-rural assignments are based on municipality, too. (see Section 3)

${ }^{15}$ See Buhre et al. (2005), Franco and Russo (2002), Meij and te Winkel (2006), and Senior and Johnson (2005).
} 
categories for wind turbines (single turbine, 2 to 9 turbines, 10 to 29 turbines, $30+$ turbines). ${ }^{16}$

Similar to openings, we investigate the effect of facility closings, examining the effect of externality removals. We focus on areas initially nearby electricity generation facilities, experiencing a closing and being outside externality distance thereafter. We compare the average price change with areas remaining in externality distance of facilities. Equation 4 shows the model, where $\mathrm{Close}_{\text {kit }}(=1)$ indicates observation $i$ being close to a closing facility of type $k$, post $t_{k i t}(=1)$ indicates observation $i$ is transacted after the closing of facility type $k$, and Treat kit $=$ Close $_{k i t} *$ post $_{k i t}$, identifies observations nearby closing facilities after closing. Similar as in Eq. 1, we control for structural and environmental characteristics by $X_{i t}$. We further control for remaining facility types. ${ }^{17}$ Finally, we investigate heterogeneity in the effects, testing for facility size in a similar manner as before.

$$
\ln \left(p_{i t}\right)=\alpha+\sum_{k=1}^{K} \gamma_{1 k}\left(\text { Close }_{k i t}\right)+\sum_{k=1}^{K} \gamma_{2 k}\left(\text { post }_{k i t}\right)+\sum_{k=1}^{K} \gamma_{3 k}\left(\text { Treat }_{k i t}\right)+X_{i t} \gamma_{4}+\epsilon_{i t}
$$

\section{Repeat Sales Analysis}

One problem of the regional difference-in-difference approach presented Section 3 is that it relies on the assumption of similar housing characteristics over time. However, even though we control for housing characteristics, we cannot rule out that transactions in affected or control areas systematically differ over time. To overcome this issue, we use repeated sales of the same property. Within our sample, there are 457,547 observations with at least one repeated sale throughout the sample period, of which 109,692 observations are sold three times, 23,959 sold four times, and 4,749 sold five times. Using the same setup, cut-off distances and time restrictions as before, we use repeated sales to measure the change in price on the same house after facility openings and closings.

We follow the approach of Aydin et al. (2016) as shown in Eq. 5. As a dependent variable, we use the percentage change in price $\Delta p_{i(t+n)}$ of property $i$ between period $t$ and $n$. Based on the previously defined cut-off distances, we measure whether a facility of type $k$ opened (closed) between the two sales within externality distance, indicated by $\triangle F A C_{k i(t+n)}=1$. We control for changes in house quality and amenities around, using vectors of control variables. We distinguish for positive changes $\Delta Q_{i(t+n)}^{\prime+}$, such as added amenities or improvements in quality, and negative changes

\footnotetext{
${ }^{16}$ We use size intervals since external effects do not necessarily increase linearly with capacity.

${ }^{17}$ It is necessary to control for nearby facility type $k$ due to unbalanced closings among types.
} 
$\Delta Q_{i(t+n)}^{\prime-}$. We control for sales year $Y_{i t}^{\prime}$ and time between two sales $(n-t)$ interacted with sales year, indicated by control vector $\Theta_{i t}^{\prime}$.

$$
\begin{aligned}
\Delta p_{i(t+n)}= & \alpha+\Delta Q_{i(t+n)}^{\prime+} \gamma_{1}+\Delta Q_{i(t+n)}^{\prime-} \gamma_{2}+Y_{i t}^{\prime} \gamma_{3}+\Theta_{i t}^{\prime} \gamma_{4} \\
& +\sum_{k=1}^{K} \beta_{k} \Delta F A C_{k i(t+n)}+\epsilon_{i(t+n)}
\end{aligned}
$$

It can be assumed that the housing market adjusts to openings / closings over time. In order to investigate the adjustment of the market to the opening / closing of facilities nearby, we control for the time difference between property sales and facility opening / closing years. We measure the year difference of observation $i$ at $t+n$ and the opening (closing) year of the nearest facility of all types $K$, indicated by $z(k)$. Since we are interested in time difference effects of treated observations $\left(\Delta F A C_{k i(t+n)}=1\right)$, we interact the time difference with $\triangle F A C_{k i(t+n)}$, indicated by $\Lambda_{(t+n)-z(k)}$. The final model is shown in Eq. 6.

$$
\begin{aligned}
\Delta p_{i(t+n)}= & \alpha+\Delta Q_{i(t+n)}^{\prime+} \gamma_{1}+\Delta Q_{i(t+n)}^{\prime-} \gamma_{2}+Y_{i t}^{\prime} \gamma_{3}+\Theta_{i t}^{\prime} \gamma_{4}+\sum_{k=1}^{K} \beta_{k} \Delta F A C_{k i(t+n)} \\
& +\sum_{k=1}^{K} \beta_{2 k} \Lambda_{(t+n)-z(k)}+\epsilon_{i(t+n)}
\end{aligned}
$$

\section{Data}

\section{Power Plants}

From various sources we collect detailed information on all major Dutch power plants, present between 1985 and 2015 and using coal, gas, biomass or a combination thereof. ${ }^{18}$ We subsequently verified and completed our data with the help of all major electricity suppliers in the Netherlands. Our data contains the number of electricity generation units, fuel types per unit, capacity per unit, year of operational start, year of closing (if applicable), and geocoded location. ${ }^{19}$ We exclude all cogeneration plants on industrial sites, cogeneration plants focusing primarily on heat generation and plants that do not produce electricity for the public grid (e.g. industrial plants). ${ }^{20}$

\footnotetext{
${ }^{18}$ These sources include:

Bijvoet, N., (n.d.), Centrale Info, http://centraleinfo.net/Europa/Nederland/index.html

Enipedia, (2010), Netherlands/Powerplants, http://enipedia.tudelft.nl/wiki/Netherlands/Powerplants

ECN, (2005), Monitoring Nederlandse elektriciteitscentrales 2000-2004, retrieved 2015 from: https://www.ecn.nl/docs/library/report/2005/c05090.pdf

19 A power plant has usually two or more electricity generation units (e.g. turbines), allowing to adjust or maintain supply. Units can be of different size (e.g. to regulate peak supply) and / or different fuel type (e.g. coal / biomass).

${ }^{20}$ Cogeneration plants on industrial sites use the byproduct hot steam to generate electricity. However, these plants are usually small and not visually recognizable within the industry complex, potentially distorting our results.
} 
The final sample includes 119 power generation units located on 45 different plant sites. Figure 3 shows the geographical distribution of the power plants in our sample. Power plants are not systematically located in low population density regions (so as to reduce possible negative externalities), but are placed rather close to urban areas, to keep supply distances in the grid short and to ensure supply stability to urban centers. Another important factor for coal and gas plants is the closeness to fuel transportation

\section{Legend}

Population per square km (per municipality)

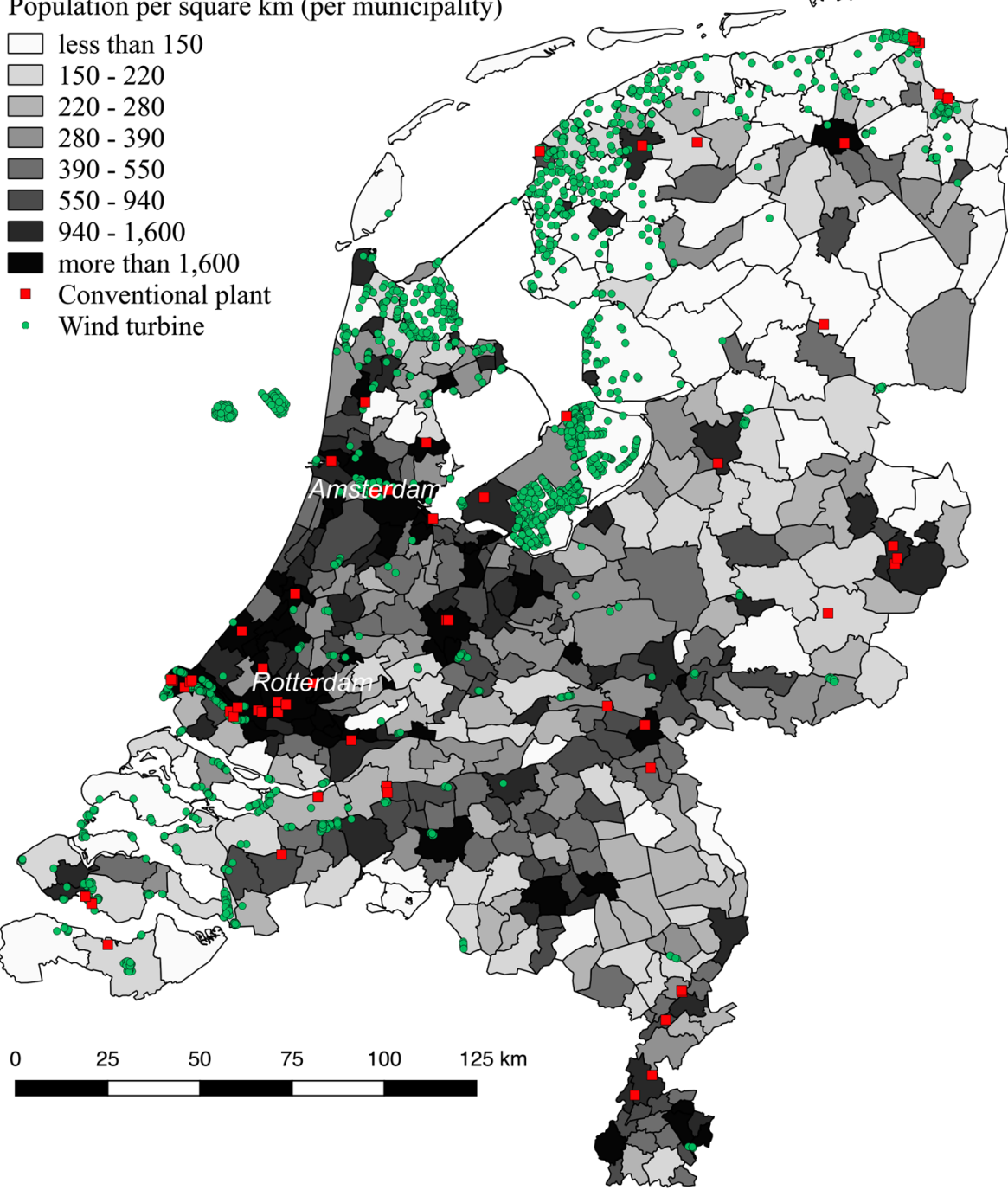

Fig. 3 Distribution of Wind Turbines, Power Plants and Population Density. Notes: The map shows the sample area (The Netherlands). Population density per municipality is illustrated by 2006 data, retrieved from the Central Statistics Office (CBS). Offshore wind parks are illustrated on the map, but not considered in the analysis 
Table 1 Conventional power plants and wind turbines. characteristics by primarily fuel type

(1)

(2)

(3)

(4)

(5)

\begin{tabular}{|c|c|c|c|c|c|}
\hline \multicolumn{6}{|c|}{ Panel A: Power plant types ${ }^{\mathrm{a}}$ (capacity in $M W$ ) } \\
\hline Type & Number of units & Total capacity & Min. capacity & Mean capacity [SD] & Max. capacity \\
\hline \multirow[t]{2}{*}{ Gas } & 95 & 22,318 & 13 & 235 & 1,275 \\
\hline & & & & [203] & \\
\hline \multirow[t]{2}{*}{ Coal } & 19 & 8,313 & 120 & 438 & 1,100 \\
\hline & & & & [288] & \\
\hline \multirow[t]{2}{*}{ Biomass } & 5 & 936 & 25 & 187 & 800 \\
\hline & & & & [343] & \\
\hline \multicolumn{6}{|c|}{ Panel B: Wind turbine characteristics } \\
\hline Characteristics & Number of units & Total capacity & Minimum & Mean $[\mathrm{SD}]$ & Maximum \\
\hline Capacity & 2,117 & $2,946,321$ & 15 & 1,393 & 7,500 \\
\hline (in kW) & & & & {$[1,066]$} & \\
\hline Height & & & 18 & 61.53 & 136 \\
\hline (in meter) & & & & [22.24] & \\
\hline Rotor diameter & & & 9 & 59.18 & 127 \\
\hline (in meter) & & & & [24.07] & \\
\hline Operational years ${ }^{\mathrm{b}}$ & & & 2 & 13 & 20 \\
\hline
\end{tabular}

Notes: Standard deviation in brackets. $1 \mathrm{MW}=1,000 \mathrm{~kW}$

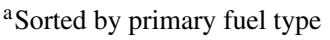

${ }^{\mathrm{b}}$ Based on 61 wind turbines that went out of operation

infrastructure, such as harbors or pipelines. It is therefore not surprising that a large number of plants are located in the Rotterdam harbor area, assuring direct access to overseas supply of gas and coal.

Panel A of Table 1 shows an overview of the number of power plants sorted by primary fuel type. Gas and coal plants are the most prevalent by number of plants and capacity, with coal providing more than ten times as much power as biomass, and gas almost three times as much as coal. However, the range of minimum and maximum capacity shows that capacity differences across power plants, for given fuel types, are quite large. For example, the smallest gas plant in our sample has a capacity of $13 \mathrm{MW}$, while the largest is almost 100 times larger. However, capacity distributions do not differ very much between fuel types. ${ }^{21}$

\footnotetext{
${ }^{21}$ While there are some plants that can use two fuel types, we classify plants by primary fuel type. To determine primary fuel type, electricity generation units must run at least 50 percent on that fuel type. Most plants were renovated and upgraded over time, to allow for a secondary fuel type. We argue that the perception and knowledge in the surrounding area is anchored to the primary fuel type (e.g. a local resident would not necessarily notice when a coal plant partly switches to biomass fuel).
} 
a

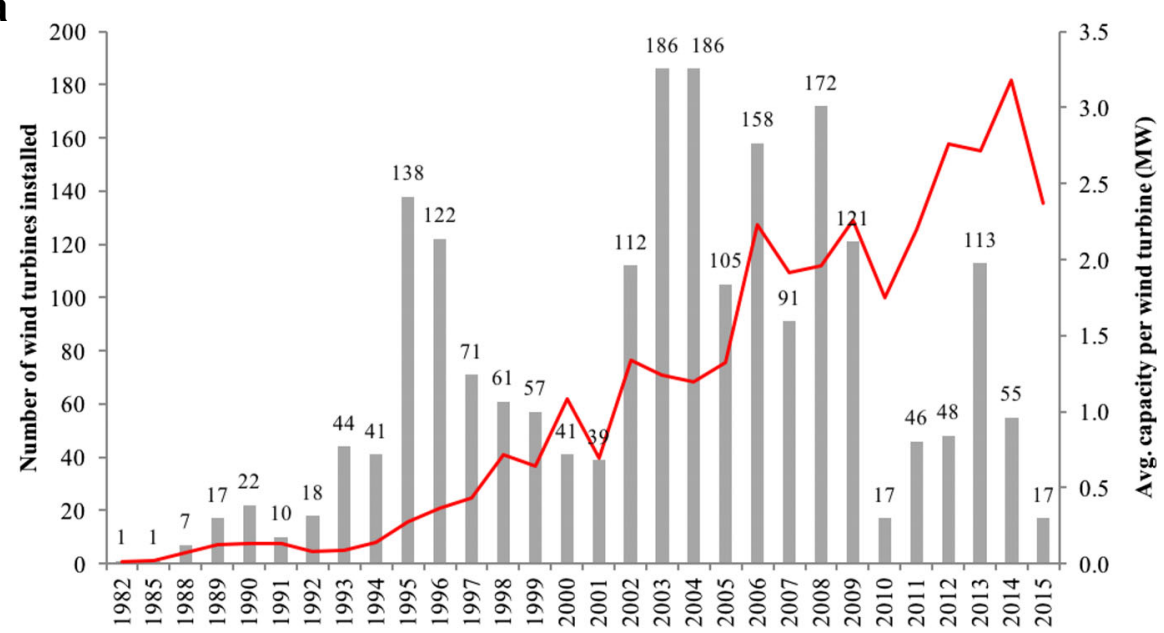

b

Wind turbines installed - Avg. installed capacity

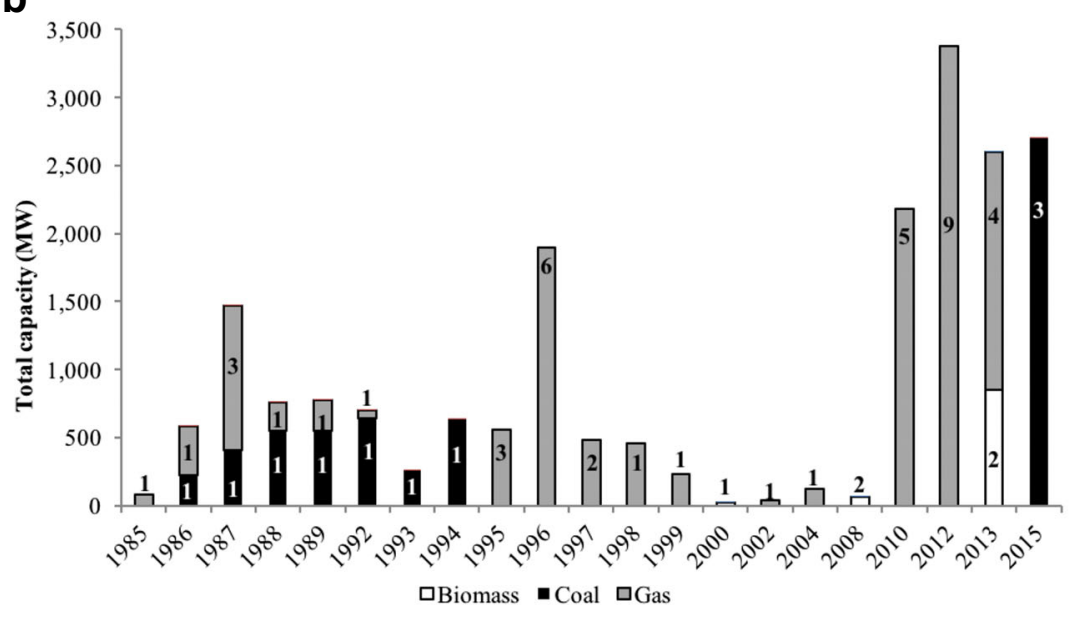

Fig. 4 Yearly Installations of Power Generation Facilities. Notes: Panel A shows the total yearly installed capacity for biomass, coal and gas plants. In addition, the respective number of electricity generation units are shown to illustrate capacity magnitudes. Since there are years without power plant openings, there are gaps in the timeline. Panel B illustrates the average capacity per wind turbine, per year installed over the respective number of units

Panel A of Fig. 4 shows the installed capacity and the respective number of electricity generation units per fuel type per year. The majority of installed units during the sample period are gas units. The first plant primarily running on biomass was 
installed in 2000. The popularity of coal energy decreased over the same period, with no new facilities added for nearly 20 years between 1994 and 2014. Only in 2015 did the utility company Essent start operating the newly built Eemshavencentrale, the Netherlands' biggest and most modern coal plant.

\section{Wind Turbines}

Information on wind turbines in the Netherlands is well-documented, including location, capacity, height, rotor diameter, setup year, dismantling year, and park affiliation. Using data from Warren and McFadyen (2010), we consider all wind turbines that were operational at some point between 1985 and 2015. Our sample consist of 2,117 individual wind turbines, clustered in 217 wind parks. Figure 3 shows the geographical distribution of all wind turbines in the sample, compared to the distribution of conventional power plants and related to population density. Most wind turbines are located in the north-western coastal area, where wind speed is highest. Furthermore, wind turbines tend to be placed in relatively low-density areas, sometimes located close to densely populated areas.

As shown in Panel B of Table 1, the average wind turbine in the Netherlands has a capacity of 1.4 MW and the largest Dutch wind turbine has a capacity of 7.5 MW, which is less than the smallest power plant in our sample. The capacity distribution of wind turbines is widely spread compared to power plants, with the largest turbine having 500 times more capacity than the smallest. Panel B of Fig. 4 shows the development of wind turbines installed in the Netherlands and the technological development over time. The average capacity per wind turbine increases over time, from $15 \mathrm{~kW}$ in 1982 to an average capacity of $3 \mathrm{MW}$. Modern wind turbines have not only more efficient generators but are also higher with larger rotor diameters. The average sample height is 61.5 meters and the average rotor diameter is 59 meter. During the sample period, 61 wind turbines were dismantled after an average life span of 13 years.

\section{Housing Transactions}

We employ a detailed dataset of housing transactions, consisting initially of nearly 3 million observations between 1985 and the first quarter of 2015. The dataset is provided by the Dutch realtors' association (NVM), which covers around 70 percent of Dutch housing transactions. The dataset contains address, transaction price, structural and environmental information, as well as sales information, such as initial asking price and time on the market. We use Bing Maps through an Application Programming Interface (API) to determine longitude and latitude information per address. After excluding double entries, outliers, and observations with incomplete information, we end up with approximately 2.3 million transactions. 
Table 2 Descriptive Statistics: Housing Sample 1985 - 2015

\begin{tabular}{|c|c|c|c|c|}
\hline \multirow{3}{*}{$\begin{array}{l}\text { Variable } \\
\text { No. of Observations }\end{array}$} & \multicolumn{2}{|c|}{ Generation facility $(<2.5 \mathrm{~km})$} & \multicolumn{2}{|c|}{ Generation facility $(>4 \mathrm{~km})$} \\
\hline & Houses & Apartments & Houses & Apartments \\
\hline & 222,399 & 117,532 & 739,818 & 343,926 \\
\hline Size & 126 & 86 & 133 & 86 \\
\hline (in m2) & {$[42]$} & {$[27]$} & [43] & [27] \\
\hline Price & 248,018 & 174,943 & 276,319 & 204,879 \\
\hline (in Euro) & {$[145,761]$} & {$[83,094]$} & {$[181,513]$} & {$[122,548]$} \\
\hline Price per $\mathrm{m} 2$ & 1,946 & 2,058 & 2,035 & 2,404 \\
\hline (in Euro) & [727] & [717] & {$[841]$} & {$[1,032]$} \\
\hline Housing inside quality & 3.04 & 2.96 & 2.98 & 2.85 \\
\hline$(1=$ worst, $9=$ best $)$ & {$[1.18]$} & {$[1.20]$} & {$[1.16]$} & {$[1.15]$} \\
\hline Housing outside quality & 3.01 & 2.91 & 2.95 & 2.80 \\
\hline$(1=$ worst, $9=$ best $)$ & [1.09] & {$[0.93]$} & [1.08] & {$[0.88]$} \\
\hline Highway within $200 \mathrm{~m}$ & 0.08 & 0.11 & 0.07 & 0.12 \\
\hline$(1=$ yes $)$ & {$[0.27]$} & {$[0.31]$} & {$[0.26]$} & {$[0.32]$} \\
\hline Urbanization & 2.58 & 1.38 & 2.98 & 1.87 \\
\hline$(1=$ highest, $5=$ lowest $)$ & {$[1.38]$} & {$[0.72]$} & {$[1.15]$} & {$[0.88]$} \\
\hline
\end{tabular}

Notes: Standard deviation in brackets. All property type mean differences between groups are significant using Welch's t-test. Inside and outside quality are ratings performed by NVM on the overall condition of the property. Both variables are measured on a scale from $1=$ best, to $9=$ worst. Highway measures whether there is a highway within 200 meters of the observation. A higher average value, shows a higher likelihood of having a highway close to the observation. Urbanization measure the level of urbanization of the respective municipality on a scale from 1 (highest) to 5 (lowest). The externality group is defined by $2.5 \mathrm{~km}$ cut-off distance for all electricity generation types. The omission corridor is of $1.5 \mathrm{~km}$ length and the control group is included up to a distance of $10 \mathrm{~km}$

We match data on power plants, wind turbines and housing transactions based on longitude and latitude, using GIS. To control for systematic differences between locations, we add additional information on the municipal level to the dataset. The Dutch Statistics Office (CBS) provides information about population density and land use per municipality, which we use to identify urban centers and rural areas. ${ }^{22}$

\footnotetext{
${ }^{22}$ We use zoning and land use data, which are available for the years between 1996 and 2015. For older years, we estimate data based on averages and time trends as land use stays relatively constant over time. Population density data are provided on the municipality level and provide a ranking from "very urbanized" to "rural". We use the first two levels ("very urbanized" and "urbanized") to define urban areas.
} 
At a cut-off distance of $2.5 \mathrm{~km}$, there are 339,931 houses within externality distance of electricity generation facilities, distributed by facility type as follows: 1,772 biomass, 10,779 coal, 152,093 gas, and 185,598 wind. ${ }^{23}$ We notice that the number of observations within "external effect" distance is limited for biomass and coal plants. Appendix Fig. 5 shows the percentage of affected observations over time. The number of observations close to coal, gas and biomass plants does not change significantly over time, whereas the number of observations close to wind turbines changes markedly. Since the spatial distribution of houses is relatively stable over time, this implies that more wind turbines get positioned close to housing over time, confirming the convergence of renewable electricity generation and urban space.

Table 2 shows the average characteristics of houses and apartments in close proximity to power plants, as well as the characteristics of homes in the control sample $(4 \mathrm{~km}<d<10 \mathrm{~km})$. There are relatively more apartments in the affected group. While apartments in both groups have roughly the same size, houses in the affected group are smaller than houses in the control group, on average. Apartments and houses tend to be lower priced in the affected group, both in absolute terms and on a per square meter basis. However, this is not necessarily due to quality characteristics or urban location, as both characteristics show that properties in affected areas are on average of better quality and in higher urbanized areas. $^{24}$

\section{Results}

\section{Difference-in-difference Results}

Appendix Table 8 shows the groupings of observations based on the described method in Section 3. We note a small number of observations for some facility types and times, forcing us to exclude coal plants from the opening analysis. ${ }^{25}$ Due to long lifespans of coal plants and the novelty of biomass and wind, we document less observations for facility closings than for openings. Appendix Fig. 6 plots the average price per square meter per year over time, examining the simultaneous trend assumption, and we notice that pre-opening and pre-closing trends follow a quite similar trend. ${ }^{26}$

\footnotetext{
${ }^{23}$ Some observations are within externality distance of different electricity generation facility types (e.g. coal and wind), thus the sum of individual electricity generation facility exposures does not match the overall number of affected observations. We test for the interaction effect of being in external distance of different electricity generation facilities, but we do not find a significant effect.

${ }^{24}$ Using Welch's t-test, all differences are statistically significant.

${ }^{25}$ The small number of observations for coal plant openings can be explained by three facts: the remote location of coal plants in general, the combined location with other facility types, such as gas plants, leading to an exclusion of observations from the pre-opening group, and the dearth of new coal plant openings over our sample period.

${ }^{26}$ Coal plants are excluded from the analysis since we do not have enough observations per year.
} 
Table 3 Results Area DID opening

\begin{tabular}{|c|c|c|c|c|c|c|}
\hline \multirow[b]{3}{*}{$\begin{array}{l}\text { Gas plant area } \\
(1=\text { yes })\end{array}$} & (1) & (2) & (3) & (4) & (5) & (6) \\
\hline & \multicolumn{2}{|c|}{ Opening effect } & \multicolumn{2}{|c|}{ Urban interaction } & \multicolumn{2}{|l|}{ Size effects } \\
\hline & $\begin{array}{l}0.039 * * \\
{[0.017]}\end{array}$ & $\begin{array}{l}0.045^{* * * *} \\
{[0.017]}\end{array}$ & $\begin{array}{l}-0.022 \\
{[0.014]}\end{array}$ & $\begin{array}{l}-0.013 \\
{[0.019]}\end{array}$ & $\begin{array}{l}0.027 \\
{[0.018]}\end{array}$ & $\begin{array}{l}0.041 * * \\
{[0.018]}\end{array}$ \\
\hline $\begin{array}{l}\text { Biomass plant area } \\
(1=\text { yes })\end{array}$ & $\begin{array}{l}0.005 \\
{[0.026]}\end{array}$ & $\begin{array}{l}-0.058 * * * \\
{[0.016]}\end{array}$ & $\begin{array}{l}-0.022 \\
{[0.032]}\end{array}$ & $\begin{array}{l}-0.072 * * * \\
{[0.016]}\end{array}$ & $\begin{array}{l}0.005 \\
{[0.026]}\end{array}$ & $\begin{array}{l}0.013 \\
{[0.026]}\end{array}$ \\
\hline $\begin{array}{l}\text { Wind turbine area } \\
(1=\text { yes })\end{array}$ & $\begin{array}{l}-0.004 \\
{[0.004]}\end{array}$ & $\begin{array}{l}-0.004 \\
{[0.004]}\end{array}$ & $\begin{array}{l}-0.012 * * * \\
{[0.003]}\end{array}$ & $\begin{array}{l}-0.004 \\
{[0.003]}\end{array}$ & $\begin{array}{l}-0.004 \\
{[0.004]}\end{array}$ & $\begin{array}{l}-0.002 \\
{[0.004]}\end{array}$ \\
\hline $\begin{array}{l}\text { Gas plant opening } \\
(1=\text { yes })\end{array}$ & $\begin{array}{l}-0.048 * * \\
{[0.021]}\end{array}$ & $\begin{array}{l}-0.057 * * * \\
{[0.021]}\end{array}$ & $\begin{array}{l}0.075 * * * \\
{[0.017]}\end{array}$ & $\begin{array}{l}0.058 * * * \\
{[0.022]}\end{array}$ & & $\begin{array}{l}-0.044^{* *} \\
{[0.022]}\end{array}$ \\
\hline $\begin{array}{l}\text { Biomass plant opening } \\
(1=\text { yes })\end{array}$ & $\begin{array}{l}0.041^{*} \\
{[0.023]}\end{array}$ & $\begin{array}{l}0.094 * * * \\
{[0.014]}\end{array}$ & $\begin{array}{l}0.021 \\
{[0.033]}\end{array}$ & $\begin{array}{l}0.089 * * * \\
{[0.015]}\end{array}$ & $\begin{array}{l}0.041^{*} \\
{[0.023]}\end{array}$ & $\begin{array}{l}0.033 \\
{[0.023]}\end{array}$ \\
\hline $\begin{array}{l}\text { Wind turbine opening } \\
(1=\text { yes })\end{array}$ & $\begin{array}{l}-0.018 * * * \\
{[0.005]}\end{array}$ & $\begin{array}{l}-0.021 * * * \\
{[0.004]}\end{array}$ & $\begin{array}{l}-0.007 * \\
{[0.004]}\end{array}$ & $\begin{array}{l}-0.014 * * * \\
{[0.004]}\end{array}$ & $\begin{array}{l}-0.017 * * * \\
{[0.005]}\end{array}$ & \\
\hline \multicolumn{7}{|l|}{ Urban openings: } \\
\hline $\begin{array}{l}\text { Gas plant urban } \\
(1=\text { yes })\end{array}$ & & & $\begin{array}{l}-0.132 * * * \\
{[0.022]}\end{array}$ & $\begin{array}{l}-0.102 * * * \\
{[0.020]}\end{array}$ & & \\
\hline $\begin{array}{l}\text { Biomass plant urban } \\
(1=\text { yes })\end{array}$ & & & $\begin{array}{l}-0.095 \\
{[0.078]}\end{array}$ & $\begin{array}{l}-0.093 * * * \\
{[0.025]}\end{array}$ & & \\
\hline $\begin{array}{l}\text { Wind turbine urban } \\
(1=\text { yes })\end{array}$ & & & $\begin{array}{l}-0.012 * * \\
{[0.006]}\end{array}$ & $\begin{array}{l}-0.003 \\
{[0.006]}\end{array}$ & & \\
\hline \multicolumn{7}{|l|}{ Facility size effect: } \\
\hline $\begin{array}{l}\text { Gas plant }(<100 \mathrm{MW}) \\
(1=\text { yes })\end{array}$ & & & & & $\begin{array}{l}0.044 * \\
{[0.024]}\end{array}$ & \\
\hline Gas plant (100 - $400 \mathrm{MW})$ & & & & & -0.028 & \\
\hline$(1=$ yes $)$ & & & & & [0.024] & \\
\hline $\begin{array}{l}\text { Gas plant }(>400 \mathrm{MW}) \\
(1=\text { yes })\end{array}$ & & & & & $\begin{array}{l}-0.050 * * \\
{[0.023]}\end{array}$ & \\
\hline $\begin{array}{l}\text { Wind turbine single }(\mathrm{n}=1) \\
(1=\text { yes })\end{array}$ & & & & & & $\begin{array}{l}-0.024 * * * \\
{[0.005]}\end{array}$ \\
\hline $\begin{array}{l}\text { Wind turbines small }(1<\mathrm{n} \\
(1=\text { yes })\end{array}$ & & & & & & $\begin{array}{l}-0.019 * * * \\
{[0.006]}\end{array}$ \\
\hline $\begin{array}{l}\text { Wind turbines medium }(10 \\
(1=\text { yes })\end{array}$ & $=\mathrm{n}<30)$ & & & & & $\begin{array}{l}-0.012 \\
{[0.008]}\end{array}$ \\
\hline $\begin{array}{l}\text { Wind turbines large }(\mathrm{n}>=3 \\
(1=\text { yes })\end{array}$ & & & & & & $\begin{array}{l}-0.028 * * * \\
{[0.008]}\end{array}$ \\
\hline Observations & $1,173,979$ & $1,087,964$ & $1,173,979$ & $1,087,964$ & $1,173,979$ & $1,173,979$ \\
\hline Adj. R-squared & 0.938 & 0.939 & 0.876 & 0.876 & 0.938 & 0.938 \\
\hline Quality controls & Yes & Yes & Yes & Yes & Yes & Yes \\
\hline Location FE & Yes & Yes & Yes & Yes & Yes & Yes \\
\hline Time FE & Yes & Yes & Yes & Yes & Yes & Yes \\
\hline Dependent Var. & lnPrice & $\ln$ Price & InPrice & lnPrice & lnPrice & $\ln$ Price \\
\hline Cut-off distance & 2.5 & 3 & 2.5 & 3 & 2.5 & 2.5 \\
\hline
\end{tabular}

Notes: Standard errors in parentheses, ${ }^{* * *} \mathrm{p}<0.01, * * \mathrm{p}<0.05, * \mathrm{p}<0.1$. All distances in $\mathrm{km}$. The maximum distance considered is $10 \mathrm{~km}$, the holdout distance is $1 \mathrm{~km}$. The opening effect dummy for coal plants is omitted, due to the small group size. Urban effects are estimated by additional urban-treatment interaction terms. Urban area is defined by the level of urbanization of the respective municipality: scale from 1 (highest) to 5 (lowest). We define municipalities above a scale of 3 as urbanized. Column (5) distinguished for different gas plant sizes, using capacity as a size indicator. Column (6) uses the number of wind turbines per park. The results of column (5) and (6) are robust for a $3 \mathrm{~km}$ cut-off distance, but not reported due to space limitations 
As shown in Table 3, we document a significant positive price effect for homes around gas plants, ranging from 4.0 to 4.6 percent and a negative price effect of 6.0 percent for homes around biomass plants, at a $3 \mathrm{~km}$ cut-off distance only. Homes in wind turbine areas show no significant price effect per se, meaning there is no ex-ante price difference. For openings, we document a negative price effect of 4.9 percent to 5.9 percent for gas plants and a negative price effect of 1.8 percent to 2.1 percent for wind turbines. In contrast, biomass plant openings lead to a positive price effect of 4.2 percent to 9.8 percent.

Examining the heterogeneity over distance, Table 4 shows the external effect results for different distance intervals. For gas plant openings, we document a positive opening effect at a distance of up to $1 \mathrm{~km}$ distance and significant negative opening effects thereafter. We do not observe enough observations within $1 \mathrm{~km}$ distance of biomass plants. Beyond this distance we document a positive opening effect thereafter. Wind turbine openings show a constant negative effect up to a distance of $4 \mathrm{~km}$. Overall, we document constant effects for wind turbines, decreasing effects for biomass plants and mixed effects for gas plants.

Differentiating urban and rural areas, we document significant location discounts for homes in biomass plant areas and wind turbine areas. ${ }^{27}$ In rural areas, we document a significant positive opening effect between 7.8 to 6.0 percent for gas plants, and 9.3 percent for biomass plant openings, while documenting a negative opening effect between 0.7 to 1.4 percent for wind turbine openings. In contrast, we document significant negative opening effects for all plant types in urban areas, ranging from an additive -14.1 to -10.7 percent for gas plants, -9.7 percent for biomass plants, and -1.2 percent for wind turbines. Our results show that electricity generation facilities are generally perceived negatively in urban areas.

Examining the interaction between plant openings and size, columns five and six differentiating for gas plant size (in capacity) and wind turbine park size (in number of turbines). We document a positive significant opening effect of 4.5 percent for small gas plants $(<100 \mathrm{MW})$ and an opening discount of 5.1 percent for large gas plants $(>400 \mathrm{MW})$. We do not document a significant opening effect for plans in the range of $100-400 \mathrm{MW}$. For wind turbine areas, we document negative opening effect of 2.4 percent for single turbines, 1.9 percent for parks up to 10 turbines, and 2.8 percent for parks with more than 30 turbines. Our results show that the negative external effects of electricity generation facility openings do not necessarily increase with facility size.

Examining the heterogeneity of openings over time, we estimate our model for different sub-periods of 10 years length as shown in Appendix Table 9. We miss sufficient number of observations for some facility types and time periods. The results are mostly in line with previous findings or insignificant. We document significant negative opening effects for gas plants in the periods 1990 - 2000 (-9.5 percent) and 2005 - 2015 (-5.1 percent). Biomass openings result in significant positive effects

\footnotetext{
${ }^{27} \mathrm{We}$ find that 92 percent of gas plants are located in urban areas, compared to 55 percent of wind turbines and 25 percent of biomass plants, suggesting that differentiating for urban locations is important.
} 
Table 4 Results Area DID opening - intervals

(1)

Opening effect

Gas plant opening $(0-1 \mathrm{~km})$

$0.034 * *$

( $1=$ yes $)$

[0.014]

Gas plant opening (1-2 km)

$-0.045^{*}$

(1 = yes)

[0.027]

Gas plant opening (2-3 km)

$-0.059 * * *$

(1 = yes)

[0.019]

Gas plant opening (3-4 km)

$-0.047 * *$

(1 = yes)

[0.018]

Biomass plant opening (1-2 km)

$-0.058$

(1 = yes)

[0.062]

Biomass plant opening $(2-3 \mathrm{~km})$

(1 = yes)

[0.014]

Biomass plant opening (3-4 km)

$0.036 * *$

(1 = yes)

[0.016]

Wind turbine opening $(0-1 \mathrm{~km})$

( $1=$ yes $)$

[0.007]

Wind turbine opening $(1-2 \mathrm{~km})$

(1 = yes)

[0.005]

Wind turbine opening $(2-3 \mathrm{~km})$

$-0.020 * * *$

(1 = yes)

[0.004]

Wind turbine opening $(3-4 \mathrm{~km})$

(1 = yes)

Observations

Adj. R-squared

0.938

Quality controls

Yes

Location FE

Yes

Time FE

Yes

Dependent Var.

lnPrice

Max. distance considered

10

Notes: Standard errors in parentheses, $* * * \mathrm{p}<0.01, * * \mathrm{p}<0.05, * \mathrm{p}<0.1$. All distances in km. The maximum distance considered is $10 \mathrm{~km}$. For space reasons, we only report the coefficients of opening effects. Due a limited number of observations, there is no estimation for biomass plant openings within $0-1 \mathrm{~km}$. We do not use a holdout group in this setup

between 2.4 to 4.2 percent throughout all available periods. Wind turbine openings result in significant negative effects of -2.4 percent for the period 1995 to 2005 , the first boom periods of wind turbines. 
Table 5 Results Area DID closing

\begin{tabular}{|c|c|c|c|c|}
\hline & (1) & (2) & (3) & (4) \\
\hline & \multicolumn{2}{|c|}{ Closing effect } & \multicolumn{2}{|l|}{ Size effects } \\
\hline Coal plant closing & -0.047 & -0.020 & -0.047 & -0.017 \\
\hline$(1=$ yes $)$ & [0.045] & {$[0.033]$} & {$[0.043]$} & {$[0.032]$} \\
\hline Gas plant closing & -0.028 & $-0.038 * * *$ & & \\
\hline$(1=$ yes $)$ & {$[0.018]$} & {$[0.014]$} & & \\
\hline Biomass plant closing & $-0.074 * * *$ & $-0.058 * * *$ & $-0.066^{* * *}$ & $-0.051 * *$ \\
\hline$(1=$ yes $)$ & {$[0.021]$} & {$[0.021]$} & {$[0.020]$} & {$[0.020]$} \\
\hline Wind turbine closing & $0.065^{* *}$ & 0.024 & $0.057^{*}$ & 0.017 \\
\hline$(1=$ yes $)$ & {$[0.032]$} & {$[0.024]$} & {$[0.032]$} & {$[0.023]$} \\
\hline \multicolumn{5}{|l|}{ Facility size interaction: } \\
\hline Gas plant (<100 MW) & & & -0.012 & $-0.023^{*}$ \\
\hline$(1=$ yes $)$ & & & {$[0.017]$} & {$[0.013]$} \\
\hline Gas plant (>100 MW) & & & $-0.053 * *$ & $-0.064 * * *$ \\
\hline$(1=$ yes $)$ & & & {$[0.022]$} & {$[0.019]$} \\
\hline Observations & 93,478 & 123,476 & 93,478 & 123,476 \\
\hline R-squared & 0.884 & 0.884 & 0.884 & 0.884 \\
\hline Quality controls & Yes & Yes & Yes & Yes \\
\hline Location FE & Yes & Yes & Yes & Yes \\
\hline Time FE & Yes & Yes & Yes & Yes \\
\hline Dependent Var. & $\ln$ Price & $\ln$ Price & $\ln$ Price & $\ln$ Price \\
\hline Cut-off distance & 2.5 & 3 & 2.5 & 3 \\
\hline \multicolumn{5}{|l|}{$\mathrm{N}$ affected by closing: } \\
\hline Coal & 134 & 132 & 134 & 132 \\
\hline Gas & 18,814 & 23,688 & 18,814 & 23,688 \\
\hline Biomass & 463 & 585 & 463 & 585 \\
\hline Wind & 416 & 339 & 416 & 339 \\
\hline
\end{tabular}

Notes: Standard errors in parentheses, $* * * \mathrm{p}<0.01, * * \mathrm{p}<0.05, * \mathrm{p}<0.1$. All distances in $\mathrm{km}$. The maximum distance considered is $20 \mathrm{~km}$, the holdout distance is $1.5 \mathrm{~km}$. The closing effect dummy for coal plants was omitted, due to the small group size. Urban effects are estimated by additional urban-treatment interaction terms. Urban area is defined by the level of urbanization of the respective municipality: scale from 1 (highest) to 5 (lowest). We define municipalities above a scale of 3 as urbanized. Due to limited variation in size (only 30 observations with $>400 \mathrm{MW}$ ), we sort gas plants around the $100 \mathrm{MW}$ cut-off. For wind turbines, we do not observe closings for parks with more than 10 turbines

Table 5 presents the results for facility closings, comparing to areas with remaining facilities. ${ }^{28}$ We document no significant closing effect for coal plants. Gas plant closings, show significant negative effects of -3.9 percent at a $3 \mathrm{~km}$ cut-off distance. For biomass plants, we document a significant negative closing effects between -

\footnotetext{
${ }^{28}$ We do not document significant facility area price effects and do therefore not report estimates for space reasons. As for all tables, complete estimation tables are available upon request.
} 
7.7 and -6.0 percent. Wind turbine removals (closings) result in positive effect of 6.7 percent at a $2.5 \mathrm{~km}$ cut-off distance. Differentiating for gas plant size, we document that negative closing effects of gas plants are higher for plants above 100

Table 6 Results repeated sales

\begin{tabular}{|c|c|c|c|c|}
\hline & $\begin{array}{l}\text { (1) } \\
\text { Opening }\end{array}$ & $\begin{array}{l}\text { (2) } \\
\text { Opening }\end{array}$ & $\begin{array}{l}\text { (3) } \\
\text { Closing }\end{array}$ & $\begin{array}{l}\text { (4) } \\
\text { Closing }\end{array}$ \\
\hline Gas plant opening & $-0.095 * * *$ & $-0.107 * * *$ & & \\
\hline$(1=$ yes $)$ & {$[0.026]$} & {$[0.028]$} & & \\
\hline Biomass plant opening & 0.021 & -0.012 & & \\
\hline (1 = yes $)$ & {$[0.024]$} & {$[0.024]$} & & \\
\hline Wind turbine opening & $-0.027 * * *$ & $-0.036 * * *$ & & \\
\hline$(1=$ yes $)$ & {$[0.006]$} & {$[0.006]$} & & \\
\hline Gas plant opening time difference & & 0.008 & & \\
\hline (no. years) & & {$[0.010]$} & & \\
\hline Biomass plant opening time difference & & $0.011 * *$ & & \\
\hline (no. years) & & {$[0.004]$} & & \\
\hline Wind turbine opening time difference & & $0.004 * *$ & & \\
\hline (no. years) & & {$[0.002]$} & & \\
\hline \multicolumn{5}{|l|}{ Closing analysis: } \\
\hline Gas plant closing & & & $0.053^{* *}$ & $0.060 * *$ \\
\hline$(1=$ yes $)$ & & & {$[0.024]$} & [0.027] \\
\hline Gas plant closing time difference & & & & 0.004 \\
\hline (no. years) & & & & [0.004] \\
\hline Observations & 228,632 & 228,632 & 15,318 & 15,318 \\
\hline Adj. R-squared & 0.726 & 0.726 & 0.715 & 0.715 \\
\hline Location FE & Yes & Yes & Yes & Yes \\
\hline Time Controls & Yes & Yes & Yes & Yes \\
\hline Dependent Var. & $\Delta$ Price & $\Delta$ Price & $\Delta$ Price & $\Delta$ Price \\
\hline Cut-off distance & 2.5 & 2.5 & 2.5 & 2.5 \\
\hline Holdout distance & 1.5 & 1.5 & 1.5 & 1.5 \\
\hline Max. distance & 20 & 20 & 20 & 20 \\
\hline
\end{tabular}

Notes: Standard errors in parentheses, ${ }^{* * *} \mathrm{p}<0.01, * * \mathrm{p}<0.05, * \mathrm{p}<0.1$. Dependent variable is the percentage change in price between sales. The time difference accounts for the time between the opening / closing and a sale, if an observation was affected by an opening / closing. We only have enough observations to examine gas plant closings. The results are robust for a $3 \mathrm{~km}$ cut-off distance, as indicated in the Appendix 
MW, ranging from -6.6 to -5.4 percent. For gas plants below $100 \mathrm{MW}$, we document a negative closing effect at $3 \mathrm{~km}$ cut-off distance, significant at $10 \%$ level. ${ }^{29}$ Overall, we document positive closing effects for wind turbines and negative closing effects for biomass and gas plants, compared to areas remaining in proximity to these facilities.

\section{Repeated Sales Results}

Since the repeated sale model analysis differs slightly from the previous specifications, we examine the fit of our model in Appendix Table 10. We document that the explanatory power is slightly lower than of our previous model specifications. The coefficients make intuitive sense and are in line with former results. In general, adding amenities or increasing quality increases property value, whereas the removal of amenities, such as a terrace, diminishes property value.

Table 6 shows the estimation results for openings and closings. We document significant negative facility opening effects for gas plants and wind turbines. Gas plant openings in the area lead to a 9.5 percentage points lower price between sales, whereas wind turbine openings result in a 2.7 percentage points lower price. The effect is robust at $3 \mathrm{~km}$ cut-off distance, as shown in Appendix Table 11. Controlling for the time between facility openings and property sales, the negative opening effect of gas plants and wind turbines remains. However, the effect diminishes over time. For wind turbines, one year difference results in an increase of 0.4 percentage points. We also document a positive effect for biomass plants (1.1 percentage points) even though we do not document a general opening effect. We do not document a significant time difference-effect for gas plants.

Since we do not observe enough transactions to investigate other closings, we focus on gas plants only. In contrast to the DID closing analysis in Section 3, we document positive closing effects of gas plants, ranging from 5.3 to 6 percentage points, not diminishing over time. However, the underlying sample of the closing analysis is small and the effects become nearly insignificant at $3 \mathrm{~km}$ cut-off distance (see Appendix Table 11) and should therefore be taken with caution.

\section{Discussion and Conclusion}

This is the first study analyzing the effects of different electricity generation types on house prices, using an extensive dataset and testing different model specifications for plant openings and closings. Our results are in line with the literature (e.g. (Davis, 2011; Dröes \& Koster, 2016; Gibbons, 2015). Wind turbines proximity and

\footnotetext{
${ }^{29}$ Unfortunately, we do not have enough variation in the sample to differentiate for urban and rural areas, as most closings occur in rural areas. Similarly, most closings occur in the years between 2005 and 2015 , not allowing to explore heterogeneity over time.
} 
openings result in negative property price effect, whereas removals of wind turbines can result in positive effects. Coal plant proximity and closings do not result in significant price effects. Gas plant proximity results in positive price effects, however decomposing the effect for openings and closings, we find that gas plant areas are higher priced compared to other electricity generation facility areas, with openings resulting in negative effects. Biomass plant proximity and openings result in positive price effects, whereas closings result in negative price effects.

Whereas the external effects differ in general, we document solely negative price effects for all facility types in urban areas. We further document that size does not play a big role, except for very small conventional plants, which seem to cause fewer external effects. Combining these two findings, we argue the external effects of electricity generation facilities do not depend on the size of the facility and negative effects outweigh potential positive effects in urban areas. We further document that some external effects, such as for coal plants, change over time, which could be due to technological developments.

The documented differences in external effects can have different reasons, such as environmental externalities (e.g. air pollution), perception, and economic effects. However, especially the latter play a big role in plant locations, since power plants generally create employment and infrastructure, such as streets (e.g. see Tiebout 1956b). In contrast, wind turbines create limited local employment and infrastructure investments. Economic external effects are generally weaker in urban areas and constant per plant, which could explain constant effects by size and negative effects for urban areas, where other external effects, such as perception, dominate. ${ }^{30}$

The documented results have strong implications for the composition of local electricity supply and placement decisions. Not only do wind turbines create less local employment, their presence also results in value losses for local home owners. Considering the average house price in our sample and average opening effects, wind turbine placements result in value losses of $€ 3,680$ to $€ 4,732$ on local houses, on average. In contrast, the opening of conventional power plants, which could run on sustainable biomass fuel, lead to positive price effects of $€ 16,562$, on average. A potential idea to compensate the negative effects from wind turbines, is to offer local residents the opportunity to co-invest in nearby wind parks. This would create local financial benefits and affect the attitude towards nearby wind turbines (Tourkolias et al., 2009).

\footnotetext{
${ }^{30}$ Back-of-the-envelope estimations from our contacts at the biggest energy suppliers in the Netherlands result in 600 - 800 jobs being created from one conventional power plant. However, we cannot confirm these statistics, since we have no access to micro-level employment data.
} 


\section{Appendix}

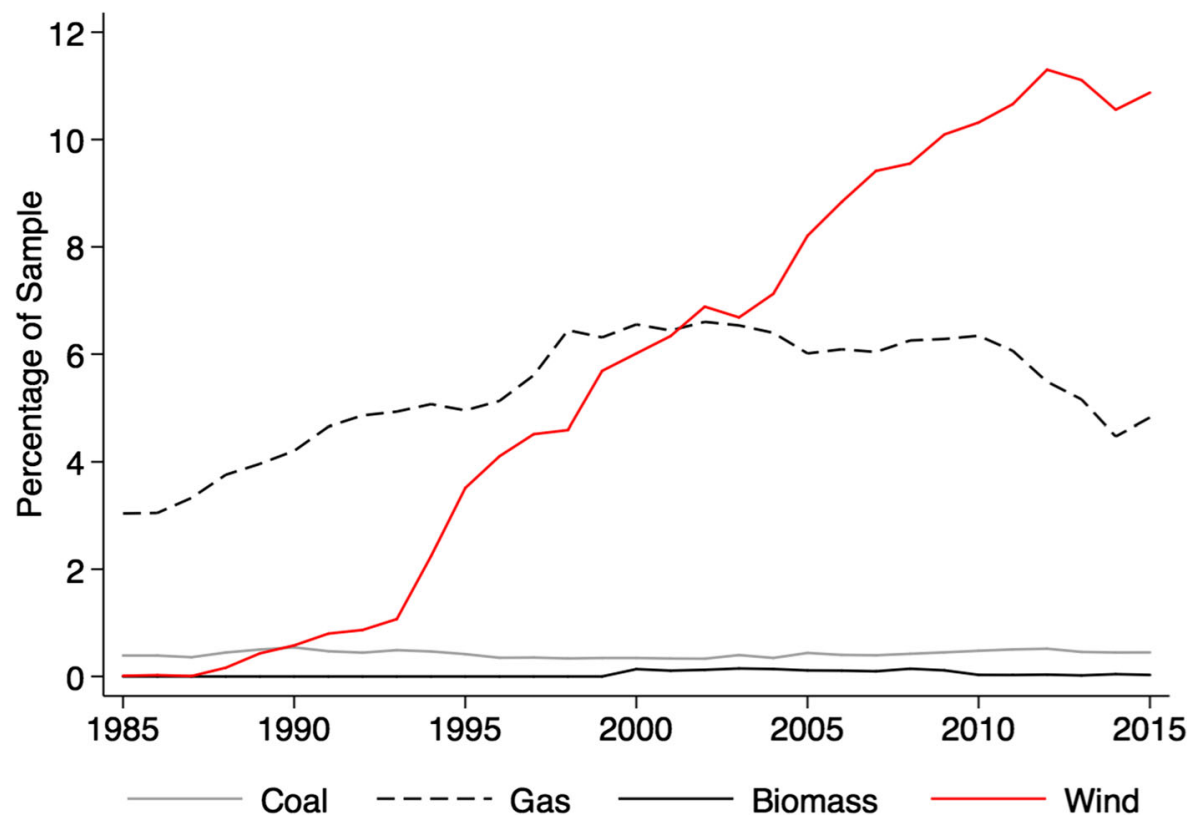

Fig. 5 Percentage of Observations Affected by Externalities (per Year). Notes: This figure shows the installation of new power plants and wind turbines, analyzing the convergence of energy generation and urban space. The yearly percentage of observations within externality distance $(2.5 \mathrm{~km})$ is illustrated 

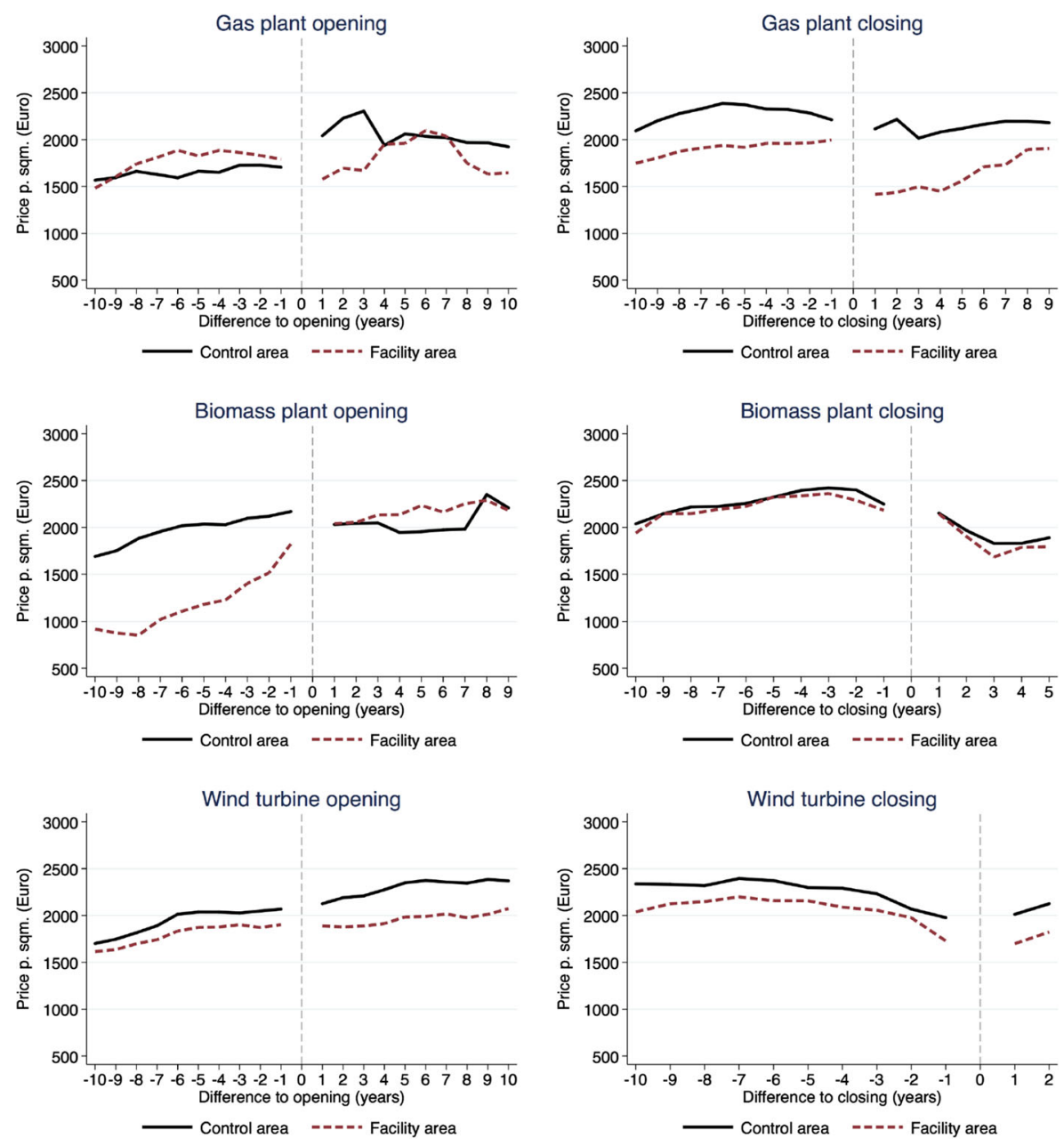

Fig. 6 Simultaneous Trend Analysis. Average price per $\mathrm{m}^{2}$ around facility openings \& closings. Notes: We compare the average price per $\mathrm{m}^{2}$ in the plant/turbine areas, prior to facility opening, with the average price per $\mathrm{m}^{2}$ in respective control areas nearby. Due to the limited number of observations, we exclude coal plant areas from the analysis. We do not have observations for all years around openings and closings, e.g. we only have observations two years after wind turbine closings. The opening / closing year is excluded from the analysis 
Table 7 Control variables

\section{Structural}

Size $\left(\mathrm{m}^{2}\right)$

Number of floors

Number of rooms

Number of bathrooms

D: Roof terrace

D: Parking lot

D: Garden

D: Garden quality bad

\section{Construction period (dummy)}

Construction 1906 - 1930

Construction 1931 - 1945

Construction 1945 - 1959

Construction 1960 - 1970

Construction 1971 - 1980

Construction 1981 - 1990

Construction 1991 - 2000

Construction 2001 and later

\section{House type I (dummy)}

Caravan

Living boat

Recreational home

Single home

Grachtenpand (old house at canal)

Manor house (without land)

Manor house (with land)

Old farm house

Bungalow

Villa

Landhouse

\section{Other}

Maintenance quality ratings (inside \& outside)

Property age (based on construction-sales year interaction)

Time fixed-effects (year)

Alternative: Time fixed-effects (year-municipality)

\author{
Apartment type (dummy) \\ Upstairs apartment \\ Two-floor apartment \\ Maisonette apartment \\ Old block apartment \\ New block apartment (suburb) \\ Apart. quality normal \\ Apart. quality luxurious
Heating type
D: Heating: coal or oven
D: Heating: central or tele-heating
D: Heating: AC or solar

\section{Insulation (dummy) \\ One level of insulation \\ Two levels of insulation \\ Three levels of insulation \\ Four levels of insulation \\ Five or more levels of insulation}

\section{House type II (dummy)}

Terraced house

Corner house

Semi-detached house

Detached house
D: Close to highway $(<200 \mathrm{~m})$
D: Close to forest $(<500 \mathrm{~m})$
D: Close to park $(<100 \mathrm{~m})$

Notes: Base values: Construction $=$ Construction before 1906, House type I = row house, House type $\mathrm{II}=$ simple house, Apart. type = ground floor, Apart. quality = bad, Garden quality: normal, Heating = no heating, Insulation = no insulation. We test two time fixed-effects, using year and year-municipality interaction. Additionally, we use location fixed-effects as mentioned in Section 3 


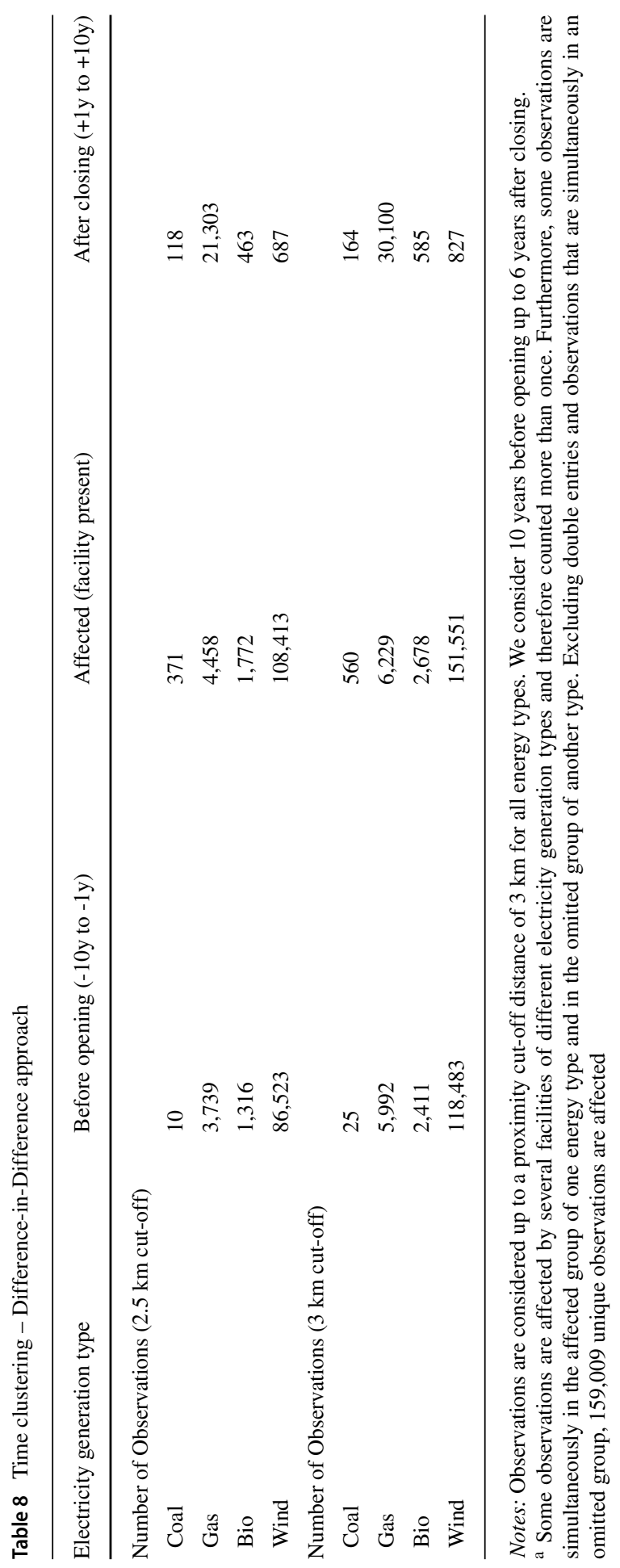




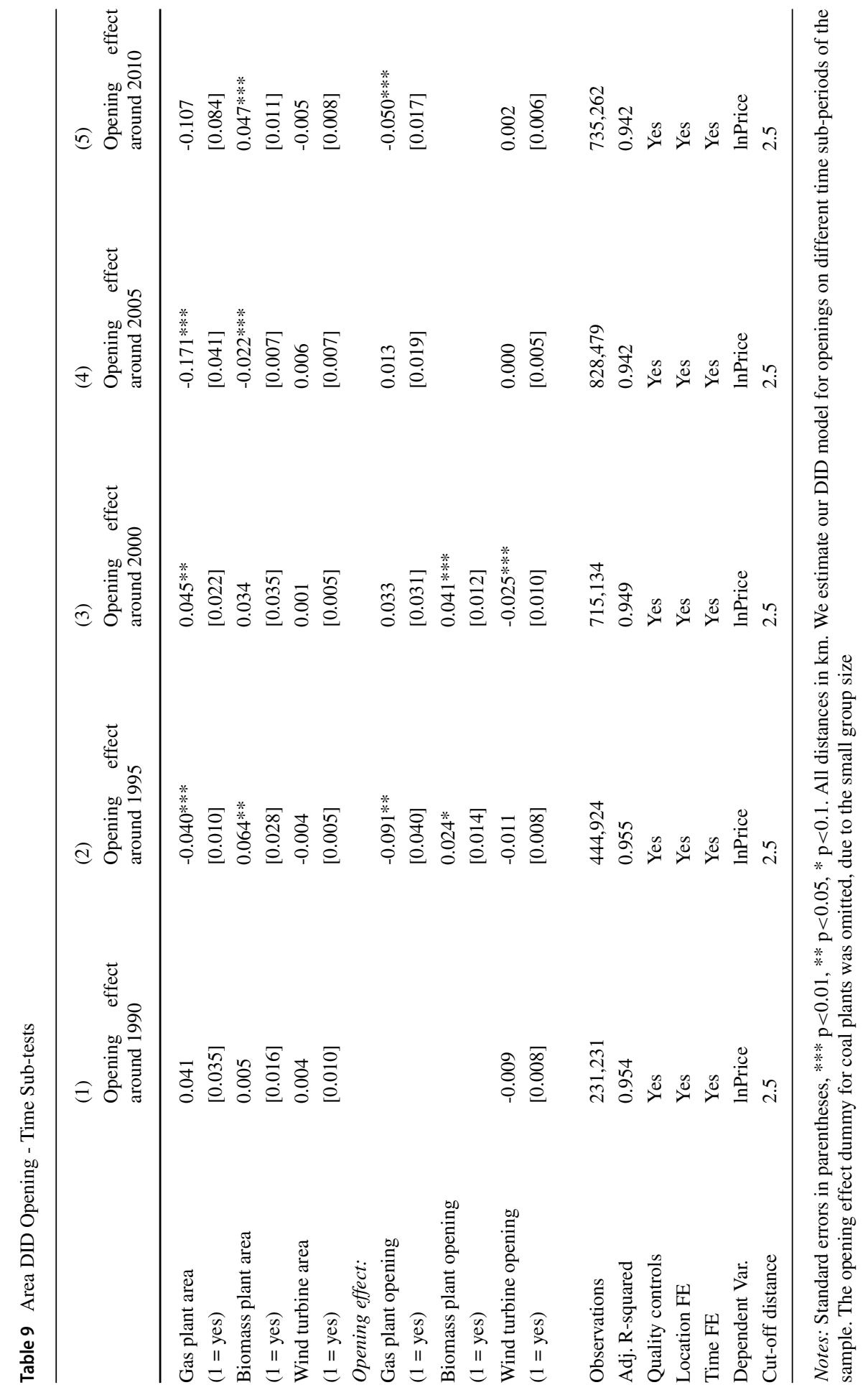


Table 10 Repeated sales. Control variables

(1)

VARIABLES

Controls

$\Delta$ size

$0.002 * * *$

$\left(\mathrm{m}^{2}\right)$

[0.000]

$\Delta$ rooms

$0.013 * * *$

(no. rooms)

[0.001]

Roof terrace removed

$-0.022 * * *$

( 1 = yes $)$

[0.003]

Roof terrace added

$0.029 * * *$

( $1=$ yes)

[0.003]

Parking removed

$-0.006^{* * * *}$

(1 = yes)

[0.002]

Parking added

$0.032 * * *$

(1 = yes)

[0.003]

Garden removed

0.001

( $1=$ yes $)$

[0.006]

Garden added

$0.040 * * *$

(1 = yes)

[0.005]

$\Delta$ layer of isolation (added)

$0.012 * * *$

(no. layers)

[0.001]

$\Delta$ layer of isolation (removed)

$-0.009 * * *$

(no. layers)

[0.000]

Observations

228,623

Adj. R-squared

0.725

Location FE

Yes

Sales Year FE

Yes

Time difference * sales year

Yes

Quality change

Yes

Dependent Var.

$\Delta$ Price

Cut-off distance

Holdout distance

1.5

Max. distance

20

Notes: Standard errors in parentheses, *** $\mathrm{p}<0.01, * * \mathrm{p}<0.05, * \mathrm{p}<0.1$. Dependent variable is the percentage change in price between sales. We measure the changes in housing characteristics over time. Some houses expand in living area or the number of rooms due to e.g. renovations. We also control for changes in the interior and exterior maintenance quality 
Table 11 Repeated Sales - 3 km cut-off distance

\begin{tabular}{|c|c|c|c|c|}
\hline Variables & $\begin{array}{l}\text { (1) } \\
\text { Opening }\end{array}$ & $\begin{array}{l}\text { (2) } \\
\text { Opening }\end{array}$ & $\begin{array}{l}\text { (3) } \\
\text { Closing }\end{array}$ & $\begin{array}{l}\text { (4) } \\
\text { Closing }\end{array}$ \\
\hline Gas plant opening & $\begin{array}{l}-0.106 * * * \\
{[0.025]}\end{array}$ & $\begin{array}{l}-0.111 * * * \\
{[0.028]}\end{array}$ & & \\
\hline Biomass plant opening & $\begin{array}{l}0.015 \\
{[0.024]}\end{array}$ & $\begin{array}{l}-0.035 \\
{[0.025]}\end{array}$ & & \\
\hline Wind turbine opening & $\begin{array}{l}-0.024 * * * \\
{[0.005]}\end{array}$ & $\begin{array}{l}-0.033 * * * \\
{[0.006]}\end{array}$ & & \\
\hline Gas plant opening time differnce & & $\begin{array}{l}0.003 \\
{[0.009]}\end{array}$ & & \\
\hline Biomass plant opening time differnce & & $\begin{array}{l}0.015^{* * * *} \\
{[0.004]}\end{array}$ & & \\
\hline Wind turbine opening time differnce & & $\begin{array}{l}0.005^{* * * *} \\
{[0.002]}\end{array}$ & & \\
\hline Gas plant closing & & & $\begin{array}{l}0.043 \\
{[0.026]}\end{array}$ & $\begin{array}{l}0.048^{*} \\
{[0.028]}\end{array}$ \\
\hline Gas plant closing time differnce & & & & $\begin{array}{l}0.003 \\
{[0.004]}\end{array}$ \\
\hline Observations & 213,698 & 213,698 & 19,307 & 19,307 \\
\hline Adj. R-squared & 0.730 & 0.730 & 0.716 & 0.716 \\
\hline Location FE & Yes & Yes & Yes & Yes \\
\hline Time Controls & Yes & Yes & Yes & Yes \\
\hline Dependent Var. & $\Delta$ Price & $\Delta$ Price & $\Delta$ Price & $\Delta$ Price \\
\hline Cut-off distance & 3 & 3 & 3 & 3 \\
\hline
\end{tabular}

Notes: Standard errors in parentheses, $* * * \mathrm{p}<0.01, * * \mathrm{p}<0.05, * \mathrm{p}<0.1$. Dependent variable is the percentage change in price between sales. The time difference accounts for the time between the opening / closing and a sale, if an observation was affected by an opening / closing. We only have enough observations to examine gas plant closings

Acknowledgements Kok is supported by a VIDI grant from the Dutch Science Foundation (NWO). We thank the NVM, the Dutch realtors' association, for providing housing transactions data, and Windstats Bosch \& Van Rijn for the data on wind turbines. We thank E.ON, Nuon Energy, and RWE / Essent for feedback on and correction of power plant data. We are grateful to Danny Ben-Shahar, Holger Bonin, Avis Devine, Véronique Flambard, Oliver Lerbs, Nikolas Wölfing and Ruchi Singh, as well as participants at the Centre for European Economic Research (ZEW) seminar, the Maastricht University Finance seminar, the 2016 UM Star Lecture Düsseldorf, the 2016 AREUEA International Conference, and the FSU-UF-UCF Symposium 2019 for their helpful feedback.

Open Access This article is licensed under a Creative Commons Attribution 4.0 International License, which permits use, sharing, adaptation, distribution and reproduction in any medium or format, as long as you give appropriate credit to the original author(s) and the source, provide a link to the Creative Commons licence, and indicate if changes were made. The images or other third party material in this article are included in the article's Creative Commons licence, unless indicated otherwise in a credit line to the 
material. If material is not included in the article's Creative Commons licence and your intended use is not permitted by statutory regulation or exceeds the permitted use, you will need to obtain permission directly from the copyright holder. To view a copy of this licence, visit http://creativecommons.org/licenses/by/4.0/.

\section{References}

Anselin, L., \& Bera, A. K. (1998). Spatial dependence in linear regression models with an introduction to spatial econometrics. Statistics Textbooks and Monographs, 155, 237-290.

Aydin, E., Brounen, D., \& Kok, N. (2016). Information Asymmetry and Energy Efficiency: Evidence from the Housing Market. Working Paper.

Ayres, R. U., \& Kneese, A. V. (1969). Production, consumption, and externalities. The American Economic Review, 59(3), 282-297.

Bakker, R. H., Pedersen, E., van den Berg, G. P., Stewart, R. E., Lok, W., \& Bouma, J. (2012). Impact of wind turbine sound on annoyance, Self-Reported sleep disturbance and psychological distress. Science of the Total Environment, 425, 42-51.

Bell, D., Gray, T., \& Haggett, C. (2005). The "Social Gap" in wind farm siting decisions: explanations and policy responses. Environmental Politics, 14(4), 460-477.

Blomquist, G. (1974). The effect of electric utility power plant location on area property value. Land Economics, 50(1), 97-100.

Breukers, S., \& Wolsink, M. (2007). Wind power implementation in changing institutional landscapes: an international comparison. Energy Policy, 35(5), 2737-2750.

Buhre, B. J. P., Elliott, L., Sheng, C. D., Gupta, R. P., \& Wall, T.F. (2005). Oxy-Fuel Combustion technology for Coal-Fired power generation. Progress in Energy and Combustion Science, 31(4), 283-307.

Carter, J. (2011). The effect of wind farms on residential property values in lee county illinois. Normal, IL.

Clark, D. E., Michelbrink, L., Allison, T., \& Metz, W.C. (1997). Nuclear power plants and residential housing prices. Growth and Change, 28(4), 496-519.

Davis, L. W. (2011). The effect of power plants on local housing values and rents. Review of Economics and Statistics, 93(4), 1391-1402.

DiPasquale, D., \& Wheaton, W. C. (1996). Urban Economics and Real Estate Markets Vol. 23. Englewood Cliffs: Prentice Hall.

Dröes, M. L., \& Koster, H. R. (2016). Renewable energy and negative externalities: the effect of wind turbines on house prices. Journal of Urban Economics, 96, 121-141.

European Commission (2003). External Costs - Research Results on Socio-Environmental Damages due to Electricity and Transport. Brussels: Office for Official Publications of the European Communities.

European Commission (2013). EU Energy, Transport and GHG Emissions - Trends to 2050. Brussels: Office for Official Publications of the European Communities.

European Commission (2015). 2020 Climate and Energy Package. Retrieved from http://ec.europa.eu/ clima/policies/strategies/2020/index_en.htm.

European Commission (2016). Climate Action - Paris Agreement. Retrieved 2016-01-01, from http://ec. europa.eu/clima/policies/international/negotiations/paris/index_en.htm.

Eurostat (2015a). Electricity Production, Consumption and Market Overview. Retrieved 201501-01, from http://ec.europa.eu/eurostat/statistics-explained/index.php/Electricity_production, _consumption_and_market_overview.

Eurostat (2015b). Renewable Energy Statistics. Retrieved 2015-01-01, from http://ec.europa.eu/eurostat/ statistics-explained/index.php/Renewable_energy_statistics.

Farboud, A., Crunkhorn, R., \& Trinidade, A. (2013). "Wind Turbine Syndrome": Fact or fiction?. The Journal of Laryngology and Otology, 127(3), 222-226.

Feld, J., van der Weijden, C., \& Wildeboer, L. (2014). Legal Developments in Wind Energy in the Netherlands. Retrieved 2015-01-01, from http://www.lexology.com/library/detail.aspx? $\mathrm{g}=\mathrm{bbf7930c}-25 \mathrm{e} 5-4140-\mathrm{afcb}-\mathrm{b} 916648019 \mathrm{c} 4$.

Franco, A., \& Russo, A. (2002). Combined cycle plant efficiency increase based on the optimization of the heat recovery steam generator operating parameters. International Journal of Thermal Sciences, 41(9), 843-859. 
Gamble, H. B., \& Downing, R. H. (1982). Effects of nuclear power plants on residential property values. Journal of Regional Science, 22(4), 457-478.

Gawande, K., \& Jenkins-Smith, H. (2001). Nuclear waste transport and residential property values: estimating the effects of perceived risks. Journal of Environmental Economics and Management, 42(2), 207-233.

Gibbons, S. (2015). Gone with the wind: valuing the visual impacts of wind turbines through house prices. Journal of Environmental Economics and Management, 72, 177-196.

Harding, G., Harding, P., \& Wilkins, A. (2008). Wind turbines, flicker, and photosensitive epilepsy: characterizing the flashing that may precipitate seizures and optimizing guidelines to prevent them. Epilepsia, 49(6), 1095-1098.

Heintzelman, M. D., \& Tuttle, C. M. (2012). Values in the wind: a hedonic analysis of wind power facilities. Land Economics, 88(3), 571-588.

Hilber, C. A. (2005). Neighborhood externality risk and the homeownership status of properties. Journal of Urban Economics, 57(2), 213-241.

Hoen, B. (2010). The Impact of Wind Power Projects on Residential Property Values in the United States: A Multi-Site Hedonic Analysis. Lawrence Berkeley National Laboratory: Lawrence Berkeley National Laboratory. Retrieved from https://escholarship.org/uc/item/0gk965bg.

Hoen, B. (2014). A spatial hedonic analysis of the effects of wind energy facilities on surrounding property values in the united states. Lawrence Berkeley National Laboratory: Lawrence Berkeley National Laboratory. Retrieved from. https://escholarship.org/uc/item/5gx7k135.

Kok, N., Monkkonen, P., \& Quigley, J.M. (2014). Land use regulations and the value of land and housing: an intra-metropolitan analysis. Journal of Urban Economics, 81, 136-148.

Krekel, C., \& Zerrahn, A. (2017). Does the presence of wind turbines have negative externalities for people in their surroundings? evidence from well-being data. Journal of Environmental Economics and Management, 82(Supplement C), 221-238.

Kuminoff, N. V., Parmeter, C. F., \& Pope, J.C. (2010). Which hedonic models CanWe trust to recover the marginal willingness to pay for environmental amenities? Journal of Environmental Economics and Management, 60(3), 145-160.

Kuminoff, N. V., \& Pope, J. C. (2014). Do "Capitalization Effects" for public goods reveal the public's willingness to pay? International Economic Review, 55(4), 1227-1250.

Lang, C., \& Opaluch, J. (2013). Effects of Wind Turbines on Property Values in Rhode Island (Tech. Rep.). Rhode Island: University of Rhode Island.

Londo, H. M., \& Boot, P. A. (2013). Het Energieakkoord: Wat Gaat het Betekenen? Inschatting van de Gemaakte Afspraken. ECN Policy Studies.

Meij, R., \& te Winkel, H. (2006). Mercury emissions from coal-fired power stations: The current state of the art in the Netherlands. Science of the Total Environment, 368(1), 393-396.

Muehlenbachs, L., Spiller, E., \& Timmins, C. (2015). The housing market impacts of shale gas development. The American Economic Review, 105(12), 3633-3659.

Nelson, J. P. (2008). Hedonic property value studies of transportation noise: aircraft and road traffic. In Hedonic Methods in Housing Markets (pp. 57-82). New York: Springer.

Pasqualetti, M. J. (2011a). Opposing wind energy landscapes: a search for common cause. Annals of the Association of American Geographers, 101(4), 907-917.

Pasqualetti, M. J. (2011b). Social barriers to renewable energy landscapes. Geographical Review, 101(2), 201-223.

Pedersen, E., \& Waye, K. P. (2007). Wind turbine noise, annoyance and Self-Reported health and WellBeing in different living environments. Occupational and Environmental Medicine, 64(7), 480-486.

Pope, D. G., \& Pope, J. C. (2015). When walmart comes to town: Always low housing prices? always? Journal of Urban Economics, 87, 1-13.

Rosen, S. (1974). Hedonic prices and implicit markets: product differentiation in pure competition. Journal of Political Economy, 82(1), 34-55.

Roth, I. F., \& Ambs, L. L. (2004). Incorporating externalities into a full cost approach to electric power generation Life-Cycle costing. Energy, 29(12), 2125-2144.

Senior, C. L., \& Johnson, S. A. (2005). Impact of carbon-in-ash on mercury removal across particulate control devices in coal-fired power plants. Energy and Fuels, 19(3), 859-863.

Sims, S., Dent, P., \& Oskrochi, G.R. (2008). Modelling the impact of wind farms on house prices in the UK. International Journal of Strategic Property Management, 12(4), 251-269. 
Sunak, Y., \& Madlener, R. (2016). The impact of wind farm visibility on property values: a spatial difference-in-differences analysis. Energy Economics, 55, 79-91.

Tiebout, C. M. (1956). A pure theory of local expenditures. The Journal of Political Economy, 64(5), 416-424.

Tiebout, C. M. (1956). A pure theory of local expenditures. The Journal of Political Economy, 64(5), 416-424.

Tourkolias, C., Mirasgedis, S., Damigos, D., \& Diakoulaki, D. (2009). Employment benefits of electricity generation: a comparative assessment of lignite and natural gas power plants in greece. Energy Policy, 37(10), 4155-4166.

Warren, C. R., \& McFadyen, M. (2010). Does community ownership affect public attitudes to wind energy? a case study from south-west scotland. Land use Policy, 27(2), 204-213.

Wolsink, M. (2000). Wind power and the NIMBY-myth: Institutional capacity and the limited significance of public support. Renewable Energy, 21(1), 49-64.

Wolsink, M. (2007). Wind power implementation: the nature of public attitudes: equity and fairness instead of 'Backyard Motives'. Renewable and Sustainable Energy Reviews, 11(6), 1188-1207.

Wüstenhagen, R., Wolsink, M., \& Bürer, M.J. (2007). Social acceptance of renewable energy innovation: an introduction to the concept. Energy Policy, 35(5), 2683-2691.

Publisher's Note Springer Nature remains neutral with regard to jurisdictional claims in published maps and institutional affiliations. 